\title{
Intrathecal Drug Administration for the Treatment of Cancer and Non-Cancer Chronic Pain
}

\author{
William Raffaeli ${ }^{2}$, Francesco Magnani ${ }^{1}$, \\ Jessica Andruccioli ${ }^{1}$ and Donatella Sarti ${ }^{1}$ \\ ${ }^{1}$ Department of Pain Therapy and Pallitive Care - Infermi Hospital- Rimini \\ 2Pain Clinic, Institute for Research on Pain "Fondazione Isal", Torrepedrera \\ Italy
}

\section{Introduction}

\subsection{Pain classification}

Pain is nowadays one of the major reasons for medical consultation worldwide. Pain is always a subjective experience, which is often verbally non-communicable. Sometimes it starts as acute pain arising from a disease (such as cancer), an injury (such as a road accident), or a post-surgical intervention; then it persists and becomes a disease itself (1-3). The International Association for the Study of Pain (IASP) definition of pain is accordingly the following: "an unpleasant sensory and emotional experience associated with actual or potential tissue damage, or described in terms of such damage" (1). Many people, however, report pain also in absence of tissue damage or any likely pathophysiological cause; usually this is due to psychological factors. For this reason pain has two components: a perceptive component, nociception, sensorial reception of the potential harmful stimulus to the central nervous system, and experiential component, individual, which is the psychological perception of an unpleasant sensation.

In relationship to the duration of painful perception, pain can be acute, or chronic. Acute pain has a short duration, and usually has a clear cause/effect, and disappear when the damage is repaired. Chronic pain is defined as pain persisting for more than 3 months, it has no prevention treatments, persists for several months or years and often does not have a single or identifiable cause.

As concerning the pathological classification of pain, there are different types of chronic pain, according to the tissues involved. Neuropathic pain, for example, is defined by IASP as "Pain caused by a lesion or disease of the somatosensory nervous system", and can be central, if "Pain is caused by a lesion or disease of the central somatosensory nervous system" or peripheral if "Pain caused by a lesion or disease of the peripheral somatosensory nervous system", including visceral organs (1). Trigeminal neuralgia, and postherpetic neuralgia are examples of neuropathic pain. 
Nociceptive pain, on the contrary, is defined by IASP as "Pain that arises from actual or threatened damage to non-neural tissue and is due to the activation of nociceptors", which are high-threshold sensory receptor of the peripheral somatosensory nervous system that is capable of transducing and encoding noxious stimuli (1). This type of pain can be somatic or visceral, according to the localizartion of tissues involved; it usually indicates a damage occurred in non-neural tissues, hence in presence of a normally functioning somatosensory nervous system to contrast with the abnormal function seen in neuropathic pain.

The two types of pain may also coexist in the same patient, in this case pain can be identified as mixed neuropatic and nociceptive.

\subsection{Cancer pain}

Pain may also be secondary to cancer, in this case is defined as cancer pain. Chronic cancer pain represents the third largest health problem in the world, and involves around $30 \%$ of the world's population (4). The World Health Organization (WHO) has stated that inadequate treatment of cancer pain represents a serious problem for public health all over the world (5). It is calculated that there are 10 million new cases of cancer and 6 million deaths from this illness worldwide. It is estimated that the incidence of cancer, currently greater in developed countries, will become more significant in developing countries as a result of the better prevention strategies being adopted in the former. The WHO program on the control of cancer has estimated that by the year 2020, around $70 \%$ of the 20 million new cases of tumours will be in the developing world, where most patients are diagnosed when the disease is already in the last stages.

More than $50 \%$ of cancer patients do not undergo adequate pain treatment (6). The pain prevents patients from carrying out normal daily activities and influences appetite, mood, self-esteem, relationships with others and mobility. In some countries it is seen that untreated pain leads to a desire for death, euthanasia or assisted suicide (4). Pain relief improves the quality of life (7).

Unfortunately, cancer pain is often not treated or is treated inadequately. The WHO have demonstrated that most, if not all, cases of cancer pain, could be treated successfully, if existing medical knowledge and suitable therapies were put into practice. There exists a lacuna in the treatment that is represented by the difference between what could be done and what is actually done in the fight against cancer pain. Training, informing health workers and facilitating access to analgesic treatments and palliative care can close this gap (5).

The WHO Expert Committee on Cancer Pain Relief and Active Supportive Care (8), stated in 1990 that "freedom from pain should be considered a right of every cancer patient and access to pain therapy as a measure of respect for this right".

In 1986, the World Health Organization, in an effort to optimize cancer pain therapy, suggested a simple three point analgesic ladder (figure 1) for the use of opioids for the treatment of cancer pain (6).

Although adoption of the therapies suggested by this analgesic ladder improves pain management in the majority of patients, it is estimated that from $5 \%$ to $15 \%$ of patients with cancer pain are unable to adequately control their pain, following these guidelines (9-11). In addition there are pains classified as "breakthrough pains" (12) which are difficult to manage 
and contain, both because they are unpredictable and because there is a lack of suitable drugs. In order to tackle this need, new drug formulations have been developed such as immediate release morphine, transmucosal fentanyl (13) and indications for invasive treatments with analgesic infusion in the liquor.

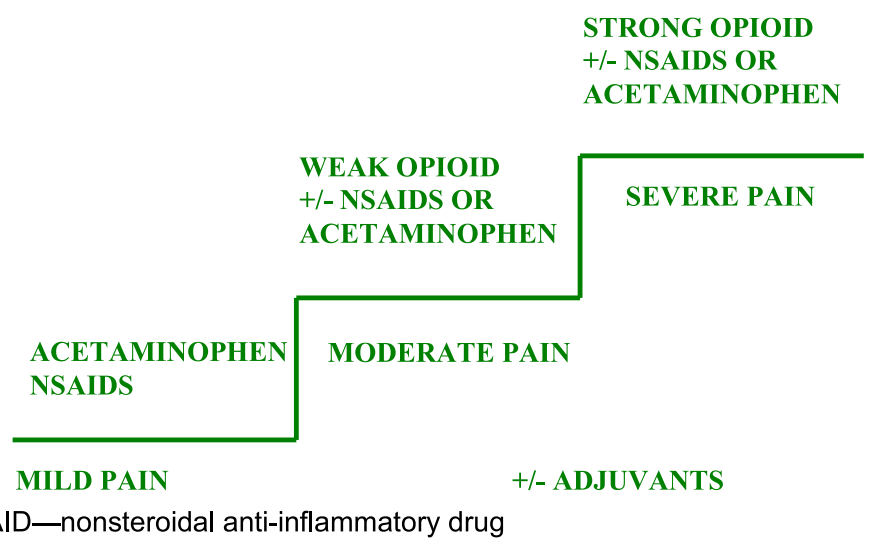

Fig. 1. The World Health Organization analgesic ladder for treating cancer pain

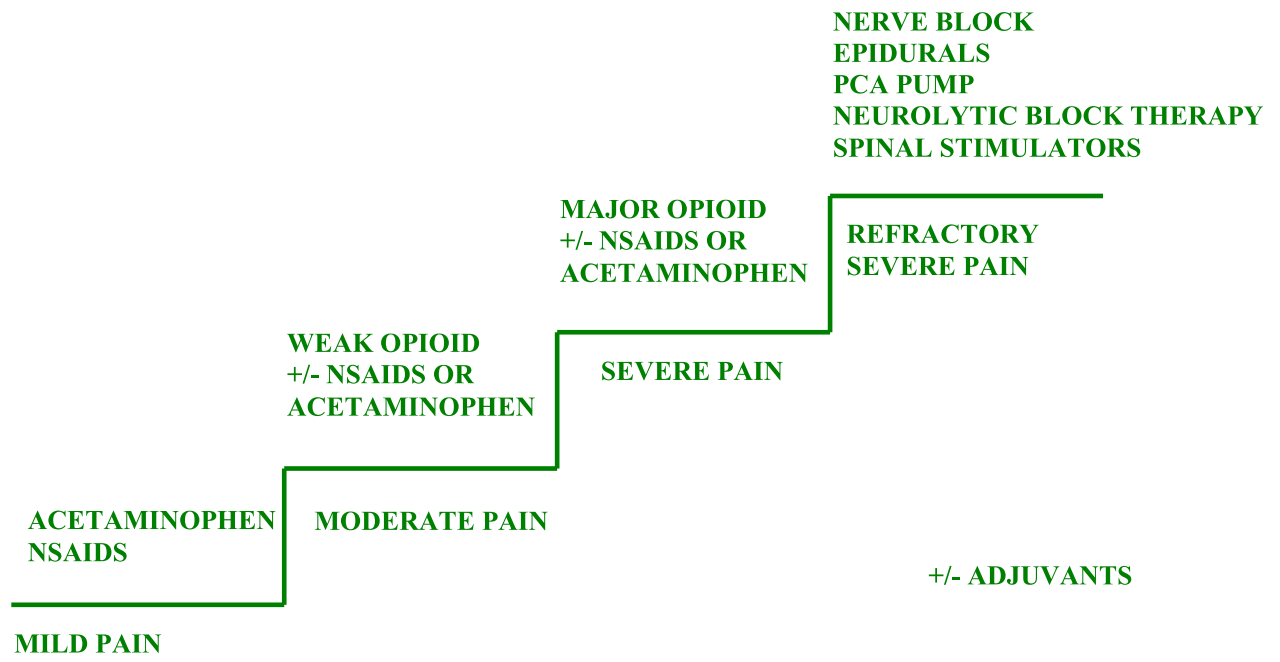

NSAID—nonsteroidal anti-inflammatory drug, PCA—patient-controlled analgesia

Fig. 2. Adaptation of the WHO ladder

Therefore, in 1997, the WHO, according to the model described by Catala, proposed a change in the analgesic ladder, adding a fourth step dedicated to intrathecal (IT) drug administration (14, 15) (figure 2). They suggested that intrathecal therapy is indicated in patients who are unable to control painful symptoms with traditional method of 
administration or in those who cannot tolerate high doses of oral opioids because of systemic side-effects.

However, while this practice has been known for a while (16-18), it has still not yet become sufficiently widespread as to define its role. When it should be used, for what pain types it is most effective and what effect it has on the biological homeostasis of the patient (18) and the development of their primary pathology.

\section{Intrathecal administration}

\subsection{History of infusion pumps}

Intratecal (IT) delivery systems for opioid infusion have been introduced in the later 1980s for the treatment of chronic pain, because of their several advantages: opioid-related systemic effects are reduced, lower opioid dosages are required, and opioid receptors are directly reached (19).

The first models of spinal analgesia were experimented in rats by Yaksh and Rudy in 1976 (19). They used morphine administered via a chronically inserted catheter, and observed that opioids elevated the analgesic threshold when the infusion was performed into the subarachnoid space. This effect was antagonized by naloxone, and had onset and duration variable according to the type of opioid used. Fentanyl onset was 2-3 minutes and expired in 20-30 minutes, whereas morphine required twice as long to start its effect, but it lasted longer, up to 2 hours.

IT therapy is a key therapeutic option for patients who have failed all other treatment avenues, require high enteral or parenteral dosages, or have unbearable opioid related-side effects (20).

The study of the spinal pathways in patients with non-malignant pain is still being developed, as there are many obstacles which prevent its widespread application. Anyway the long-term intrathecal administration with totally implantable systems has been recommended for the treatment of noncancer pain, both by a consensus of specialists from the United States in 1997 (21) and by the International Consensus Conference in Brussels in 1998 (22). Experts believe that it should be used in pathologies characterized by the presence of long-term persistent pain, where other therapeutic strategies have been judged to be ineffective or inapplicable because of serious adverse effects (23).

\subsection{IT drugs}

There are five main classes of IT drugs: opioids, including morphine, hydromorphone, sufentanil, fentanyl, methadone, and ,meperidine; local anaestetics, such as bupivacaine, ropivacaine, and tetracaine; adrenergic agonist: clonidine and tiazinidine; N-methyl-Daspartate (NMDA) antagonist, including dextrorphan, dextromethorphan, mematine and ketamine; other agents, such as baclophen, ziconotide, midazolam, neostigminie, aspirin, and droperidol (24).

Opioids are a heterogeneous group of synthetic and semisynthetic opium derivates, their analgesic effect and therapeutic use is lost in time. The power of an opioid depends on 
several factors: affinity with their receptor, specific pharmacological potency, or the ability to express the desired effect. The amount and type of receptors in a tissue affects the response to opioids in terms of both quality and quantity (intensity and duration of effect).

Intratecal infusion of major opioids is increasingly used for the treatment of chronic pain, and morphine is the gold standard (25). Morphine delivered IT, and its metabolites, especially morphine-6-glicuronide (M-6-G) (26), can provide prolonged analgesic because there is a slow replacement of the cerebrospinal fluid (CSF) over time, and it is approximately ten time more potent than the same amount administered systemically or epidurally (27-29). In the chronic infusion, M-6-G plays a larger role; it enters the CSF from the plasma, but can also be created in situ by the brain (30-32).

Hydromorphone administered intratecally has been less applied, and few studies are present in the literature. It is known to be 5 times more potent than morphine, but the adverse events profile is equivalent or better than that of morphine (33).

Bupivacaine belongs to the amino amide group; it is known to act synergistically with the opioids for the treatment of pain (34-36) allowing the administration of lower doses of morphine to achieve the same analgesic effect (37). The use of IT bupivacaine has been shown to be free of bone marrow toxicity and to have positive synergy with opioids $(35,36)$. Despite the excellent results obtained with morphine and bupivacaine, there still remains difficulty in treating all pains, particularly the pains of neuropathic origin.

Clonidine has been shown to be helpful in difficult to treat cases. It has been reported that the spinal administration of clonidine not only acts synergistically when administered with opioids, increasing the analgesic power and reducing side-effects (38), but it is also a powerful analgesic agent when used alone, especially for the treatment of neuropathic pain (39-41).

Local anesthetics and opioids work on differing analgesic systems, so low doses of these agents, when added to each other IT, provide analgesic synergy (42). Moreover, the use of a low dose of bupivacaine when added to IT morphine allows for a low dose of morphine thereby reducing the incidence of opioid-related side-effects (43). Although morphine is the gold standard agent used for IT therapy, experts in the field of IT therapy today use a variety of drug combinations, such as morphine/bupivacaine, hydromorphone, and morphine/clonidine $(32,44)$.

An interdisciplinary expert panel of both physicians and non-physicians in the field of intrathecal therapies met in 2007 at the Polyanalgesic Consensus Conference, in order to update previous recommendations/guidelines for the management of pain by IDDS (45). They suggested the following classification and drug dosages (table.1).

Morphine and ziconotide are approved by the Food and Drug Administration of the United States for intrathecal analgesic use and are recommended for first line therapy for nociceptive, mixed, and neuropathic pain. Hydromorphone is recommended based on clinical widespread usage and apparent safety. Fentanyl is a line 2 agent and is reccommended by the consensus conference when the use of the more hydrophilic agents of line 1 (morphine, ziconotide) result in intractable supraspinal side effects (table 2). 


\begin{tabular}{|l|l|}
\hline IT drug type & Maximum dose/day (mg) \\
\hline Morphine & 15 \\
\hline Hydromorphone & 4 \\
\hline Fentanyl & Unknown upper limit \\
\hline Sufentanil & Unknown upper limit \\
\hline Bupivacaine & 30 \\
\hline Clonidine & 1.5 \\
\hline Ziconotide & $19.2 \mathrm{mcg}$ \\
\hline
\end{tabular}

Table 1. IT drug doses as recommended by the polyanalgesic consensus 2007.

\begin{tabular}{|c|c|}
\hline Line & IT drug \\
\hline 1 & $\begin{array}{l}\text { a) morphine } \\
\text { b) hydromorphone } \\
\text { c) ziconotide }\end{array}$ \\
\hline 2 & $\begin{array}{l}\text { d) fentanyl } \\
\text { e) morphine/hydromorphone + ziconotide } \\
\text { f) morphine/hydromorphone + } \\
\text { bupivacaine/clonidine }\end{array}$ \\
\hline 3 & $\begin{array}{l}\text { g) clonidine } \\
\text { h) morphine/hydromorphone/fentanyl + } \\
\text { bupivacaine + clonidine + ziconotide }\end{array}$ \\
\hline 4 & $\begin{array}{ll}\text { i) } & \text { sufentanil } \\
\text { j) } & \text { sufentanil +bupivacaine + clonidine + } \\
\text { ziconotide }\end{array}$ \\
\hline 5 & $\begin{array}{l}\text { k) ropivacaine, buprenorphine, midazolam } \\
\text { meperidine, ketorolac }\end{array}$ \\
\hline 6 & $\begin{array}{l}\text { I) Experimental Drugs: gabapentin, } \\
\text { octreotide, conopeptide, Neostigmine, } \\
\text { Adenosine, XEN2174, AM336, XEN, ZGX } \\
160\end{array}$ \\
\hline
\end{tabular}

Table 2. Recommended algorithm for intrathecal polyanalgesic therapies, 2007. 
Combinations of opioid/ziconotide or opioid/bupivacaine or clonidine are recommended for mixed and neuropathic pain and may be used interchangeably. Clonidine alone or in combination with opioids such as morphine/ hydromorphone /fentanyl; bupivacaine and/or clonidine mixed with ziconotide are line 3 agents, and may be used when agents in line 2 fail to provide analgesia or side effects occur when these agents are used. Sufentanil alone or mixed with bupivacaine and/or clonidine plus ziconotide (suggested for neuropathic pain) is recommended in line 4. Midazolam and octreotide are line 5, and should be tried when all other agents in lines 1-4 have failed in end-of-life patients. Experimental agents are line 6, and must only be used experimentally and with appropriate Independent Review Board (IRB) approved protocols (45).

IT drug administration can be performed through bolus or continuos infusion. Bolus administration may result in better distribution of anesthetic solution compared with continuous infusion of the same anesthetic solution. Automated methods of bolus injection, moreover, may combine the advantages of manual boluses and continuous infusion, while sparing on drug consumption.

The constant infusion, however, is the most diffused method of IT drug administration, and the comparison between bolus and constant-flow pumps shows no difference as concerning efficacy and safety in non-cancer pain $(46,47)$ and cancer pain $(48)$.

\subsection{Opioid receptor}

Opioid action is mediated by the activation of opioid receptors. The receptors are several and the major are called $\mu, \mathrm{k}$ and $\delta$, are responsible for both the positive effects (analgesia), but also of opioid related side effects (respiratory depression, itching, vomiting etc.) (table 3 ).

\begin{tabular}{|c|c|c|c|c|}
\hline $\begin{array}{l}\text { Opioid } \\
\text { receptor type }\end{array}$ & Function & $\begin{array}{l}\text { Endogenous } \\
\text { peptides }\end{array}$ & Agonist & Antagonist \\
\hline$\mu$ & $\begin{array}{l}\text { Subtype } \mu 1 \text { : analgesia } \\
\text { Subtype } \mu 2 \text { : adverse events } \\
\text { (Sedation, vomiting, respiratory } \\
\text { depression, pruritus, euphoria, } \\
\text { anorexia, urinary retention) and } \\
\text { physical dependence }\end{array}$ & $\begin{array}{l}\text { Enkephalins } \\
\beta \text {-Endorphin } \\
\text { Dynorphin A }\end{array}$ & $\begin{array}{l}\text { Morphine } \\
\text { Codeine } \\
\text { Fentanyl } \\
\text { Meperidine } \\
\text { Methadone }\end{array}$ & $\begin{array}{l}\text { Naloxone (Weak) } \\
\text { Naltrexone }\end{array}$ \\
\hline$\delta$ & Analgesia, spinal analgesia & $\begin{array}{l}\text { Enkephalins } \\
\beta \text {-Endorphin }\end{array}$ & $\begin{array}{l}\text { Codeine (weak) } \\
\text { Meperidine }\end{array}$ & $\begin{array}{l}\text { Naloxone (Weak) } \\
\text { Naltrexone (Weak) }\end{array}$ \\
\hline K & $\begin{array}{l}\text { Analgesia, sedation, dyspnea, } \\
\text { psychomimetic effects, miosis, } \\
\text { respiratory depression, euphoria, } \\
\text { dysphoria, dyspnea }\end{array}$ & Dynorphin A & Morphine (Weak) & $\begin{array}{l}\text { Naloxone } \\
\text { Naltrexone }\end{array}$ \\
\hline
\end{tabular}

Modified from ref. 49

Table 3. Major Opioid receptors

The opioid receptor is a macromolecule that includes an extracellular N-terminus, 7 transmembrane helical twists, 3 extracellular and intracellular loops, and an intracellular Cterminus (49) (Fig. 3). Once the receptor is activated, it releases the inhibitory G protein, which diffuses within the membrane and activates a cascade of biochemical reactions leading to the decrease of cAMP intracellular. The final result is the neuronal inhibition, blocking the release of excitatory neurotransmitters (Fig. 4). This block is obtained inducing changes (inhibition) of calcium channels activity in pre-synaptic neurones and alterations of hyperpolarization (activation of potassium channels) in postsynaptic neurones (terenius). 
The binding sites of the various opioid receptors are sufficiently flexible to accommodate structurally different ligands and to allow selectivity in the activation. (table 3).

Extracellular space

N-terminus

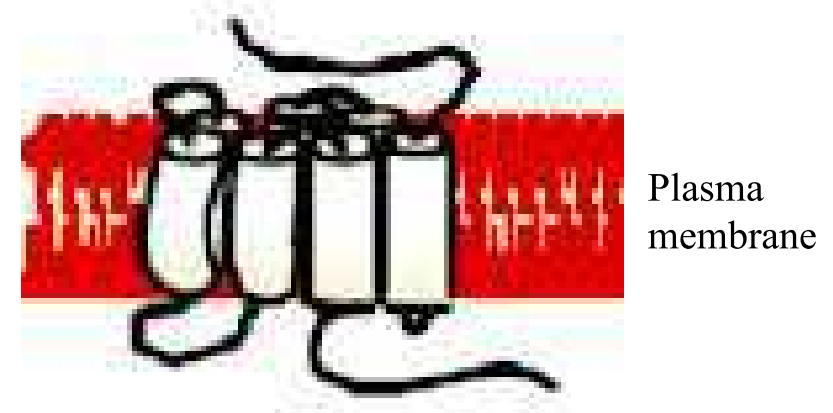

Cytoplasm

C-terminus

Fig. 3. Opioid Receptors structure

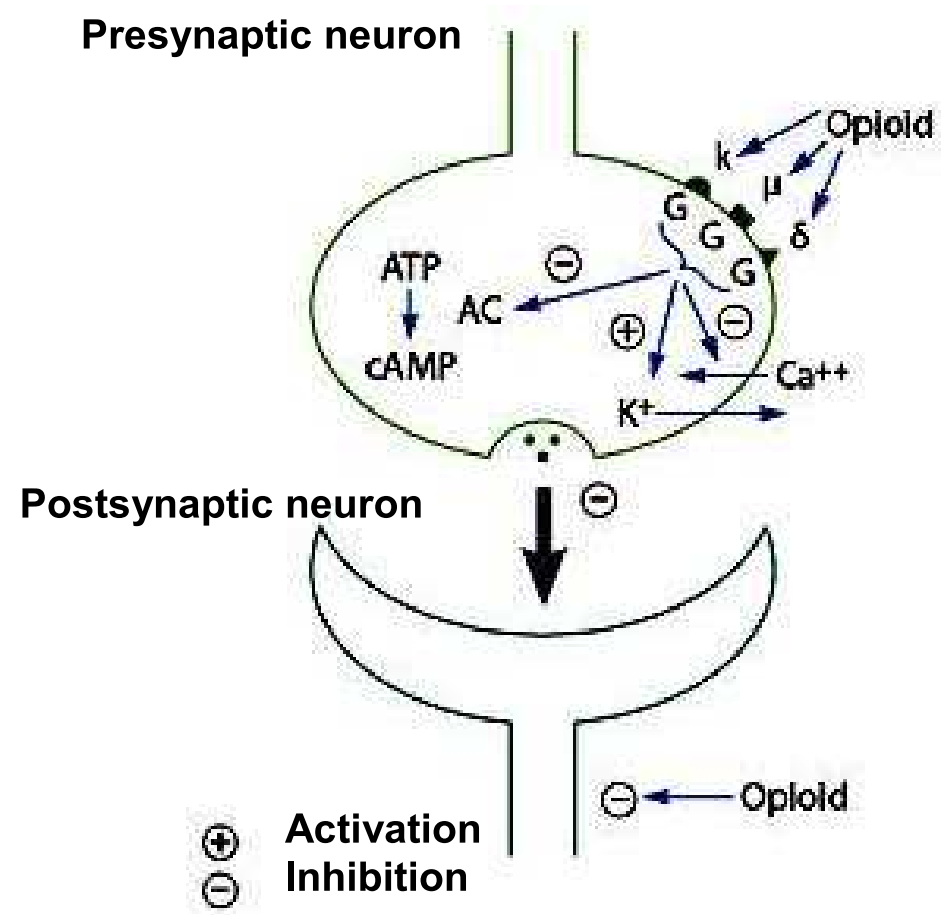

Fig. 4. Opioid Receptor signalling (Modified from ref. 49) 
Most of the common opioids, such as morphine, codeine and fentanyl, are agonists of opioid receptors, and act by stimulating them with different intensity and efficacy.

Opioid receptor partial agonists, such as buprenorphine, on the contrary, bind with high affinity, but low efficacy at the mu receptor (partial effect). These agents can be used as analgesics, but have a ceiling to their analgesic effect, and increasing the dose beyond a certain threshold will not result in a corresponding increase in efficacy, but only in greater side effects (49).

Opioid receptor Agonists-Antagonists, such as pentazocine, nalbuphine, and butorphanol, have poor mu opioid receptor efficacy, acting as functional antagonist, and kappa agonistic properties, causing undesired dysesthesias. As the partial agonist, they have a partial or a complete ceiling to their analgesic effect. (49).

The opioid receptor antagonists, naloxone and naltrexone, are competitive antagonists at the $\mathrm{mu}$, kappa, and delta receptors, in particular, with a high affinity for the mu receptor, but lacking any mu receptor efficacy, hence they do not activate the opioid cascade. (49).

\subsection{Biological consequences of long-term intrathecal administration of opioids}

In the last years data have been accumulated on the biological effects of systemic administration of morphine (50-52). Less is known about the effects of spinaly administered opioids on various body systems which are not purely nociceptive.

Biological systems are characterized by an accurate mechanism of auto-control. Indeed, we call homeostasis the tendency to uniformity or stability in the normal body states (internal environment or fluid matrix) of the organism. This tendency aims at maintaining the organism under optimal physiological condition (53). Whenever a biological system is altered, a congruent cascade of physiological response is activated to eliminate the perturbation factor and to circumscribe the effects of the biological answer to that perturbation. Examples for such behaviour are the immune and the endocrine system. The homeostatic regulation of these systems normally occurs through a feedback mechanism, driven by their own products. Moreover, it is known that many regulatory molecules may exert their effect, directly or indirectly, on more than one system. Cytokines, the principle mediators of the immune system, are a known example for such regulatory molecules. Homeostasis fails when the feedback mechanism is overwhelmed by the perturbation factor or when a positive feedback occurs and the biological answer is perpetuated, not being counterbalanced by a suitable reaction in the opposite sense.

A growing body of evidence suggests that exogenous and endogenous opioids influence both the endocrine and the immune systems and that they share many properties of the cytokines (54). This concept is of an extreme clinical relevance. Indeed, as opioids are shown to have a regulation role of the above mentioned systems, a careful insight is needed to understand the biological impact of their utilization in long term pain treatments.

\subsection{Opioid Immunomodulation}

Exogenous opioids are known to mediate immunosuppression, while endogenous opiates enhance immune function (54). In vitro, the augmentation of natural killer (NK) cell activity by endogenous opiates is antagonized by naloxone (55). These findings are consistent with 
the notion that opioid receptors are expressed by immunocytes. Administration of opioids has been associated with increased vulnerability to infections in humans and with reduced survival in animals bearing tumours. In fact, administration of opioids inhibits NK cell activity, immune response, cytokine expression and phagocytosis.

Both central and peripheral mechanisms are implied in the exogenous opioids immunosuppression. Central mechanism may involve both the hypothalamic-pituitaryadrenal pathway and the autonomic nervous system. It is believed that the latter is implied during acute administration of morphine whereas the former during chronic administration. It is noteworthy that in the periphery, cytokines may induce endogenous opioids secretion from immunocytes and influence both analgesia and inflammation. On the other hand, exogenous opioids may induce the secretion and the expression of inflammatory cytokines in peripheral immunocytes. Thus opioids may be considered as an important inflammation and immune regulatory molecules.

Modulation of immune response by central opioid receptors has been described (56-60). It has been reported that such modulation involves the delayed-type hypersensitivity reactions and humoral immune responses. Moreover, it appears that central immune modulation is influenced by the type of the activated opioid receptor, as well as by the source and nature of the opioid agonist. Indeed, different endogenous opioid effect differentially humoral and cell mediated immune responses by differentially activating brain $\mu, \delta$ and $\kappa$ opioid receptors. Permissive central immunomodulatory action of endogenous opioids seems to be mediated by the $\mu$ and $\delta$ receptors while suppression by the $\kappa$ receptor (54). Further, acute administration of morphine seems to alter immune response through the activation of the sympathetic system while long term morphine administration decreases lymphocyte proliferation and NK cell activity by the modulation of the hypothalamic-pituitary-adrenal axis (61). Moreover there is a direct correlation with the way of administration and that the intraspinally way cause an important immunosupressive effect on NK and lymphokine activated killer (LAK) cells cytotoxic activity via a second messenger probably prolactin (PRL) mediated (15) and an interfrence on u-receptor expression (62).

So, opiates widely influence the immune system and may be considered as cytokines. Opioid receptors that mediate immunomodulation are located in the central nervous system, peripheral sensory neurons, and immunocytes. Activation of these receptors exerts direct or indirect immunomodulation in a complex fashion. Exogenous opioids tend to suppress cellmediated immune function especially when administered systemically. Hence, the route of exogenous opioid administration may play an important role in preventing immunosuppression. Indeed, theoretically, the intrathecal route may avoid central and peripheral opioid receptors and hence reduce the likelihood of opioid immunosuppression (54).

\subsection{Opioid and the endocrine system}

Opioids are known to interfere with the neuroendocrine function (63). Animals and humans studies have explored both the acute and the chronic neuroendocrine effects of opiates and different opioid peptides. Acute administration of opioids in humans increases the secretion of PRL, growth hormone (GH), thyroid-stimulating hormone (TSH), and adrenocorticotropic hormone (ACTH) while it inhibits the release of luteinizing hormone (LH) $(64,52)$. It has been argued that the inhibition of $\mathrm{LH}$ release is mediated through central inhibition of 
hypothalamic GnRH secretion (65). Opioids influence on endocrine pathways and products is mediated by endogenous opioid legands. It has been reported that PRL and TSH secretion is probably modulated by the $\varepsilon$ and $\mu$ receptors, respectively while ACTH secretion by $\delta$ or $\mathrm{K}$ receptors; $\varepsilon$ receptors are thought to be involved in the inhibitory control of LH $(66,67)$. The receptors involved in $\mathrm{GH}$ modulation have not been established yet.

Endocrine response to chronic administration of opioids differs from that of acute administration. In fact, the increased secretion of PRL, seen in the acute setting is increased only by systemic administration and not by intraspinally administration. No change in the TSH and $\beta$-endorphin secretion has been reported (62). Exogenous opioids are known to exert an inhibitory effect on the concomitant release of $\beta$-endorphin and ACTH through a feedback mechanism. Such mechanism may explain the suppression of ACTH release in long term opioid administration (68).

It has been reported recently that long term intrathecal opioid therapy induces hypogonadotropic hypogonadism (69) and that altered sexual function and low testosterone levels may be observed in individuals addicted to opioids or on methadone maintenance or in males with chronic non-cancer pain treated with intrathecal opioids $(70,71)$.

In conclusion, chronic opioid administration influence multiple endocrine functions. Data on this issue are scantly regarded in the literature. Yet, the advent of endocrine effects of opioid therapy cannot be ignored as it has no doubt an extraordinary clinical relevance especially in young adults. Particular attention should be paid to wether the administration route of chronic opioid therapy has any influence on the endocrine response to long term opioid therapy.

\subsection{Indications and contraindication for IT therapy}

Intrathecal analgesia is a key pain therapy for patients who have failed other treatment routes as well as patients with adequate analgesia on high dose enteral or parenteral therapy but with unacceptable side effects. The current body of literature supports the use of intrathecal agents for the treatment of moderate or severe pain related to cancer and noncancer origins (72).

It emerges, in particular, that the evidence for opioid intrathecal infusion efficacy was strong for short-term improvement in pain of malignancy or neuropathic pain (73). The evidence was moderate for long-term management of persistent pain, and reasonably strong for longterm therapy of cancer pain. The evidence supporting long-term efficacy in persistent noncancer pain is however less convincing (73).

As concerning more specifically the type of pain responding to IT morphine, it is effective for long-term treatment of neuropathic-nociceptive, peripheral neuropathic, deafferentation and nociceptive pain, resulting in significant improvement over baseline levels of visual analog scale pain (74). Other types of pain indicated for IDDS are failed back syndrome, axial spinal pain, complex regional pain syndrome, widespread pain, central pain, pain nonresponding to spinal cord stimulation (SCS), arachnoiditis, central neuropathic pain (poststroke, spinal cord).

Intrathecal delivery systems (IDDSs) have also short-term clinical success in pain control, reduce significantly common drug toxicities, and improved survival in patients with refractory cancer pain (75). 
The most important authors use and results on cancer and non cancer pain are reported in tables 4 and 5 .

\begin{tabular}{|c|c|c|c|c|c|}
\hline Authors & Patients & $\begin{array}{l}\text { Pain } \\
\text { intensity } \\
\text { before } \\
\text { treatment }\end{array}$ & Treatment & $\begin{array}{l}\text { Length of } \\
\text { treatment }\end{array}$ & Results \\
\hline $\begin{array}{l}\text { Van Dongen } \\
\text { et al., } 1999 \\
(110)\end{array}$ & $\begin{array}{l}20 \text { patients, } \\
\text { mean age } 55 \text { years }\end{array}$ & $\begin{array}{l}\text { I. NRS } \\
5-9 / 10 \\
\text { II. NRS } \\
6-10 / 10\end{array}$ & $\begin{array}{l}\text { I. IT morphine } \\
\text { II. IT morphine/ } \\
\text { bupivacaine. }\end{array}$ & $\begin{array}{l}\text { I. 51-191 } \\
\text { days } \\
\text { (mean 85) } \\
\text { II. 22-154 } \\
\text { days } \\
\text { (mean 58) }\end{array}$ & $\begin{array}{l}\text { The group with morphine/bupivacaine } \\
\text { showed a slower increase rate in the IT } \\
\text { morphine dose ( } r=0.0003 \text { ) compared to } \\
\text { the group with morphine alone } \\
\text { ( } r=0.005) \text {. } \\
\text { I. NRS } 2-4 / 10 \\
\text { II. NRS } 1-4 / 10\end{array}$ \\
\hline $\begin{array}{l}\text { Smith et al., } \\
2002 \text { (111) }\end{array}$ & $\begin{array}{l}101 \text { patients mean } \\
\text { age } 56.2 \text { _ } 13.2 \\
100 \text { comprehensive } \\
\text { medical } \\
\text { management } \\
(\mathrm{CMM})\end{array}$ & $\begin{array}{l}\text { VAS } \\
7.57 / 10\end{array}$ & $\begin{array}{l}48 \text { with morphine, } 2 \\
\text { morphine/clonidine, } 36 \text { with } \\
\text { hydromorphone, } 15 \\
\text { hydromorphone/bupivacain } \\
\text { e }\end{array}$ & 4 weeks & $\begin{array}{l}71 \text { IDDS patients }(84.5 \%) \text { achieved } \\
\text { clinical success, } 52 \% \text { pain reduction, } \\
\text { and } 37.2 \% \text { of } \\
\text { the CMM group }\end{array}$ \\
\hline $\begin{array}{l}\text { Rauck } \\
\text { et al., } 2003 \\
(112)\end{array}$ & $\begin{array}{l}119 \text { patients, mean } \\
\text { age } 60.6 \pm 13.5 \\
\text { years }\end{array}$ & VAS $6.1 / 10$ & $\begin{array}{l}\text { IT morphine sulphate (initial } \\
\text { dose } 1.8 \\
\text { mg/day and } 5.2 \mathrm{mg} / \text { day at } 4 \\
\text { months). }\end{array}$ & 13 months & $\begin{array}{l}\text { Excellent results } \geq 50 \% \text { reduction in } \\
\text { NAS, in the use of systemic opioids or in } \\
\text { the opioid complication severity index) } \\
\text { observed in } 83 \%, 90 \%, 85 \% \text { and } 91 \% \text { of } \\
\text { patients at } 1,2,3,4 \text { months } \\
\text { respectively. }\end{array}$ \\
\hline $\begin{array}{l}\text { Smith et al } \\
2005(113)\end{array}$ & $\begin{array}{l}52 \text { patients average } \\
\text { age } 56.2 \pm 13.2 \\
45 \text { comprehensive } \\
\text { medical } \\
\text { management } \\
(\mathrm{CMM}) \text { average age } \\
57.8 \pm 13.7\end{array}$ & \begin{tabular}{|l|} 
VAS \\
$7.44 / 10$ \\
and \\
$7.59 / 10$ \\
respectively
\end{tabular} & $\begin{array}{l}\text { Morphine oral equivalent } \\
\text { dose (mg/day) } 260 \text { and } 280 \\
\text { respectively }\end{array}$ & 12 weeks & $\begin{array}{l}82.5 \% \text { of IDDS patients had clinical } \\
\text { success compared with } 77.8 \% \text { of } \\
\text { comprehensive medical management } \\
\text { (CMM) }\end{array}$ \\
\hline
\end{tabular}

Modified from ref. 109

Table 4. Intraspinal therapy: cancer pain

\begin{tabular}{|c|c|c|c|c|c|}
\hline Authors & Patients & \begin{tabular}{|l|} 
Pain \\
intensity \\
before \\
treatment \\
\end{tabular} & Treatment & $\begin{array}{l}\text { Length of } \\
\text { treatment }\end{array}$ & Results \\
\hline $\begin{array}{l}\text { Willis e } \\
\text { Doleys, } 1999 \\
(114)\end{array}$ & $\begin{array}{l}29 \text { patients, } \\
\text { mean age } \\
57.79 \text { years }\end{array}$ & VAS $8.91 / 10$ & Intraspinal therapy & 31 months & $\begin{array}{l}\text { VAS } 5.03 / 10 \text {. } \\
\text { Improvement in pain }(63.4 \%) \text {, in level of } \\
\text { activity }(45.5 \%) \text {, in performing activity } \\
(53.8 \%) \text {. } \\
86 \% \text { of patients reported good or } \\
\text { excellent results. } \\
50 \% \text { of patients reported side effects. }\end{array}$ \\
\hline $\begin{array}{l}\text { Brown et al., } \\
1999(115)\end{array}$ & $\begin{array}{l}38 \text { patients, } \\
\text { mean age } \\
48.84 \text { years } \\
\text { (lower back } \\
\text { pain) }\end{array}$ & & $\begin{array}{l}\text { IT opioids }(3.23 \pm 0.54 \\
\text { mg meq./d in the first } 6 \\
\text { months and } 18.58 \pm \\
2.93 \text { mg meq./d at } 48 \text { - } \\
54 \text { months }\end{array}$ & $\begin{array}{l}\text { Mean } 50 \\
\text { months }\end{array}$ & $\begin{array}{l}\text { Patients reported a reduction in pain of } \\
64 \% \text { and both they and their families } \\
\text { were satisfied with the treatment. } \\
\text { Despite these benefits, there was } \\
\text { substantial weakening in physical } \\
\text { functionality and a high number of side } \\
\text { effects. }\end{array}$ \\
\hline $\begin{array}{l}\text { Roberts et } \\
\text { al., } 2001 \\
(116)\end{array}$ & $\begin{array}{l}88 \text { patients, } \\
\text { mean age } 53.4 \\
\text { years }\end{array}$ & & $\begin{array}{l}\text { IT morphine } \\
(9.95 \pm 1.49 \mathrm{mg} / \text { day } \\
\text { at } 6 \text { months and } 15.26 \pm \\
2.52 \mathrm{mg} / \text { day at } 36 \\
\text { months })\end{array}$ & 36.2 months & $\begin{array}{l}\text { Mean pain reduction of } 60 \% \text { in the } 74 \% \\
\text { of patients who report an increase in } \\
\text { level of activity. } \\
88 \% \text { of patients are satisfied. }\end{array}$ \\
\hline $\begin{array}{l}\text { Franco Gay, } \\
2002(117)\end{array}$ & $\begin{array}{l}39 \text { patients, } \\
\text { mean age } 63.4 \\
\text { years }\end{array}$ & $\begin{array}{l}\text { VAS } \\
5-10 / 10\end{array}$ & $\begin{array}{l}\text { IT morphine (initial } \\
\text { dose } 0.5 \text { and final dose } \\
2 \text { mg/day)/ bupivacaine, } \\
\text { clonidine. }\end{array}$ & $\begin{array}{l}36 \text { months - } \\
6.5 \text { years } \\
\text { (mean } 2.2 \\
\text { years) }\end{array}$ & $\begin{array}{l}55.6 \% \text { reported excellent results, } 22.2 \% \\
\text { good. } \\
\text { Level of activity: } 30.5 \% \text { good, } 61 \% \text { fair, } \\
3 \% \text { poor, } 5.5 \% \text { no change. } \\
91 \% \text { of patients were satisfied with the } \\
\text { treatment. }\end{array}$ \\
\hline $\begin{array}{l}\text { Grider et al } \\
2011(118)\end{array}$ & 22 patients & $\begin{array}{l}\text { VAS } 7.3 \pm \\
1.9 / 10\end{array}$ & $\begin{array}{l}\text { IT morphine, average } \\
\text { dosage } 335 \mathrm{mcg} / \mathrm{day}\end{array}$ & 12 months & Average pain VAS reduction of $53.4 \%$ \\
\hline
\end{tabular}

Table 5. Intraspinal therapy :non-cancer pain 
The implantation of IDDS is contraindicated (surgical contraindication) in every case of serious cardiovascular disease, coagulation disorders, anatomical abnormalities of the spine and/or bone infections, in place, CSF fistulas, abnormal CSF flow, anatomical malformations that impede the creation of a pocket for the pump accommodation. There are also opioid-related contraindications, including severe respiratory failure, intolerance to opiates, and opioid non-responsiveness as emerged from pre-implant spinal test.

\subsection{IT devices}

Intrathecal drug administration is usually provided by a programmable Infusion Pump, a small machine implanted in patients' bodies (fig. 5) which allow IT infusion of drug stored in their reservoir (fig. 6). Their electronic and mechanic devices work with precision and reliability and allow liquid infusion for some hours to few months' periods, during that time a strict control of the amount infused is essential. In this way pump therapy allows drug administration only when it's required, keeping drug amount between prescribed limits. The benefits of an infusion pump are summarised in table (6).
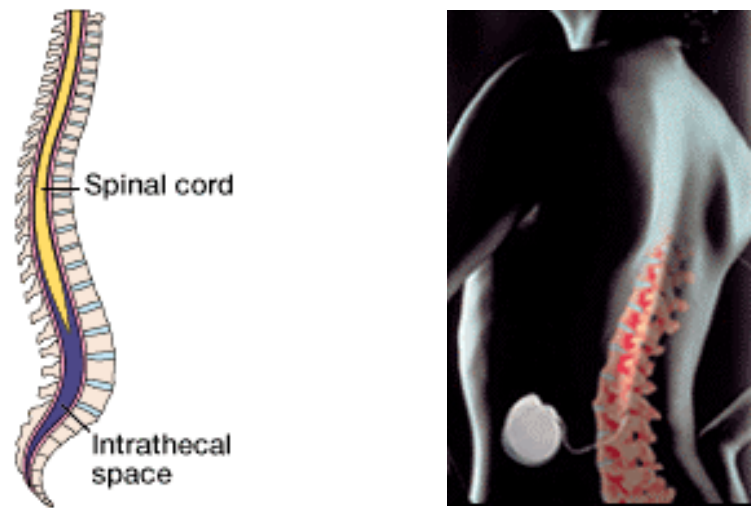

Fig. 5. Spinal Space and localization of the Infusion pump

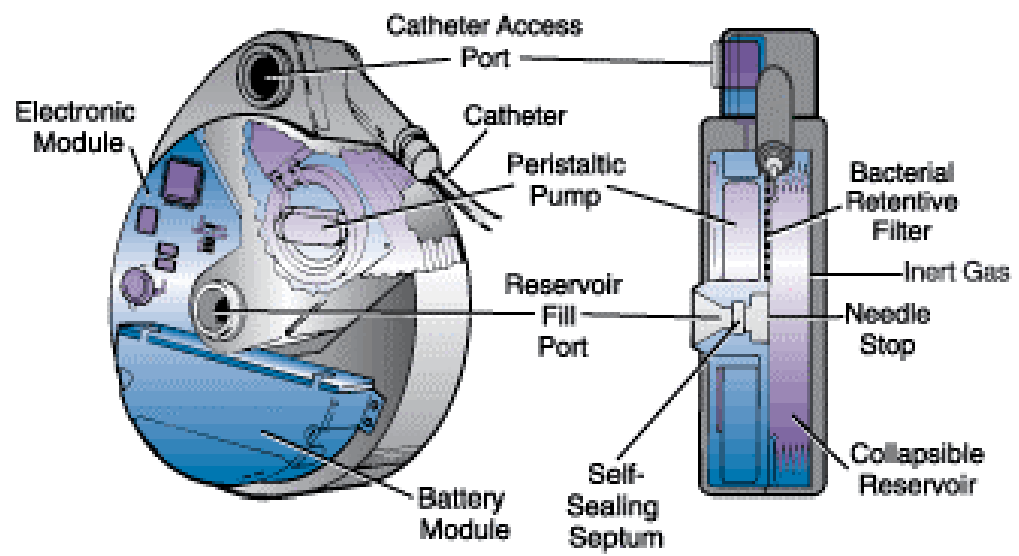

Fig. 6. Characteristics of infusion pump 


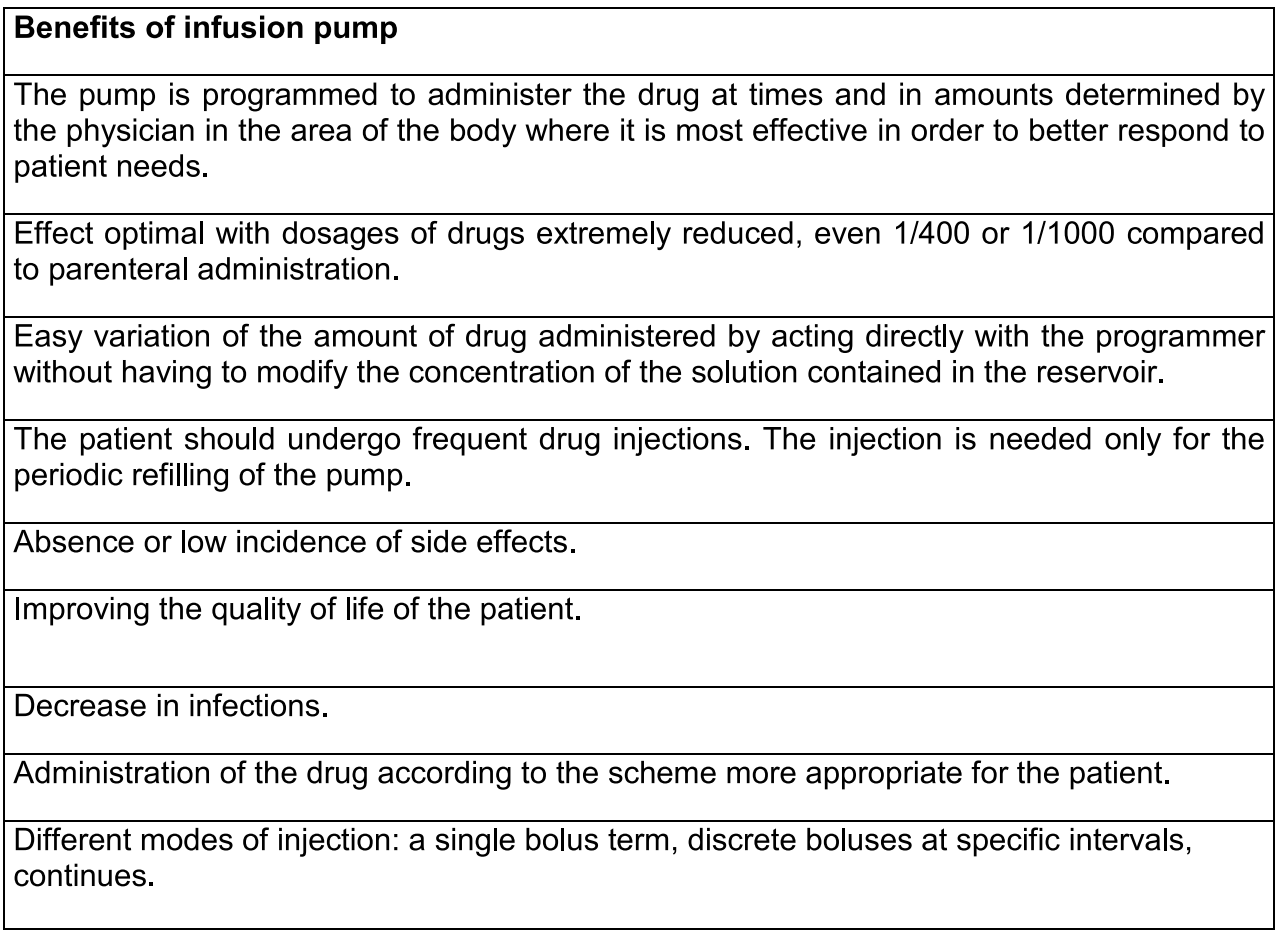

Table 6. Benefits of infusion pump

All systems of infusion are constituted by two implanted components: a pump and a catheter. The pump has a central reservoir where it stores and delivers the drug daily basis the amount prescribed. This reservoir has a filling port, which is used for the refilling. The pump is provided with an antibacterial filter and of a point of secondary access, which allows a direct access to the catheter and consequently to the space where this ends, that the doctor may use to administer drugs or solutions directly in the catheter, skipping the pump. The catheter is a flexible tube connected to a port of the pump, and brings the drug to the area of the body designated.

A surgical operation is required for the implantation of a programmable pump and a catheter in the body. The potential risks correlated with the implantation are: infection to the point of implantation; displacement, blockage or entanglement of the catheter; run out of the pump internal battery; breakage of device components, requiring a pump replacement.

The core of the infusion system, which is commonly called pump, is a metal disc with a diameter of $7 \mathrm{~cm}$ and a thickness of $3 \mathrm{~cm}$ (weight $180 \mathrm{gr}$.), which is made entirely of titanium and silicon (highly bio-compatible materials). The pump is provided with an antibacterial filter and of a point of secondary access, which allows a direct access to the catheter (a small tube a few millimeters in diameter and 20 to $30 \mathrm{~cm}$ long silicone). Each type of pump has its specific catheter, which are sold together.

The pump includes 3 sealed chambers: one containing the propellant of the reservoir, the second a hybrid electronic module and the battery and the third contains a peristaltic pump 
and reservoir for the drug (fig. 6). The peristaltic pump pushes the drug through an elastomeric connector, from the reservoir to a catheter, and then up to the site of administration.

The electronic circuits control the pump function, while the valve of the prevents the further introduction of fluid into the reservoir once it reaches its full capacity. This type of pump is reliable and more secure compared to other systems with gas propellants, as it is not affected by variations in temperature or pressure, ensuring an accurate control of the amount to be infused.

The reservoir for the drug has a capacity of 18-20 ml (Isomed and Syncromed) or $40 \mathrm{ml}$ (Archimedes), and is made of titanium. The electronic circuit is composed of: a lithium thionyl chloride battery, with 44 months of autonomy to a continuous flow of 0.5-1 ml / day (Isomed, Archimedes respectively) or less in case of the syncromed model; an antenna allowing the contact with the operator.

The electronic module is the system memory, where are stored all the data such as the drug concentration, residual quantity, unit of measurement and data relative to the infusion programme (amount and timing).

It is possible to perform rest periods, filling the pump with saline solution thus allowing for a continuous washing of the catheter, as a prevention of the risk of occlusion resulting from the return of blood, in the case the catheter remains empty for a long time.

Refilling operations are limited to the puncture (fig. 7), through the skin with a Huber needle, of the self-sealing septum, which can be localized with palpation by the physician.

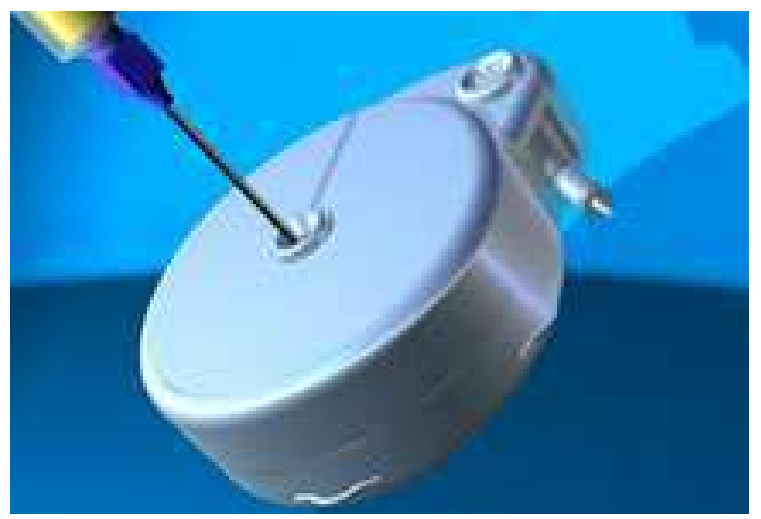

Fig. 7. Refilling procedure

A programmer interacts with the pump by establishing a contact in radiofrequency (fig. 8) thanks to which you can get a report of the programming parameters and of the prescription of medication (quantity and time of infusion). There are different models of pump, but can be divided into 2 types: fixed flux and electronic pumps, which are fully programmable via an external computer with telemetry head, they are battery powered and can last from 5 to 7 years of life, the most popular model is the Synchromed (fig. 9). 


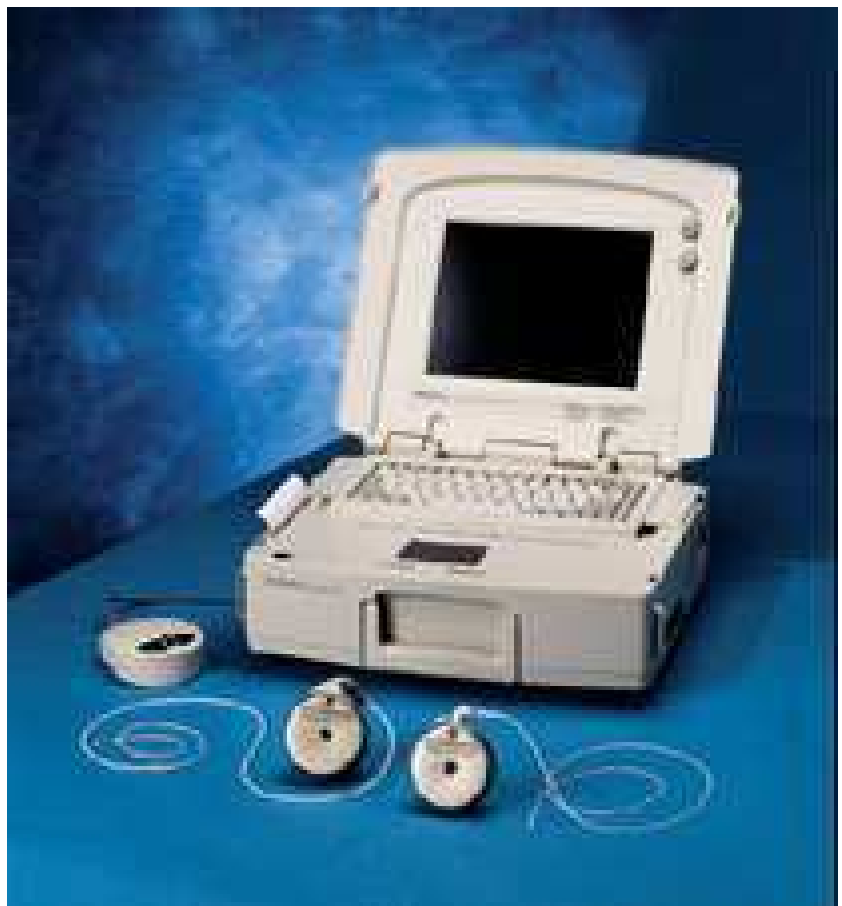

Fig. 8. Pump programer

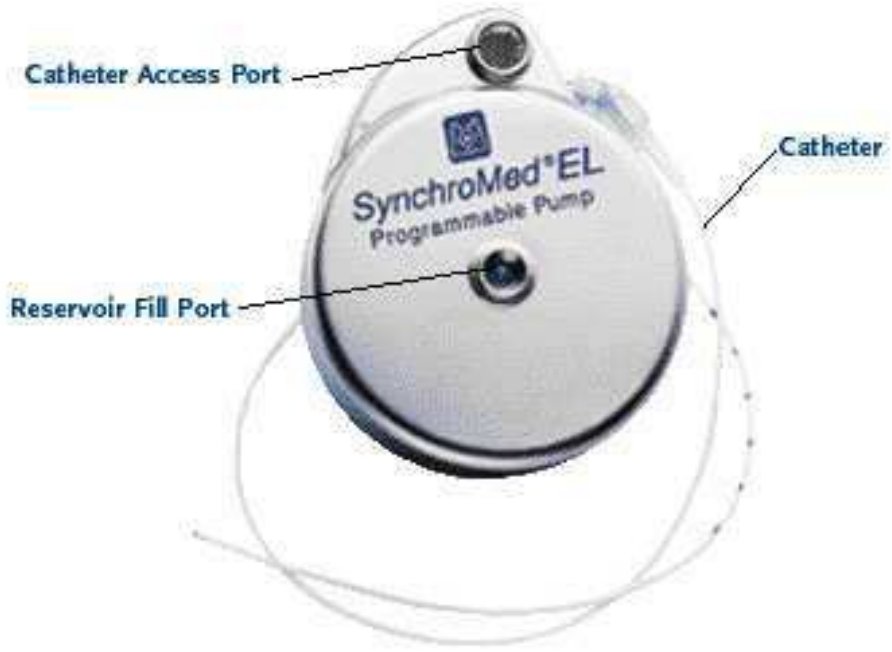

Fig. 9. Programmable infusion pump

The programmable parameters for Syncromed type of pumps are the following: date and time of refilling; identification of the patient, name and concentration of the drug; mode of 
infusion, dosage of the drug and rate of administration; volume of the reservoir and low alarm setting reservoir; low battery alarm control (acoustic).

The Syncromed (Medtronic Italia, S.p.A., Rome, Italy) pumps are, moreover, supplied of acoustic alarm systems, which signal: drug in exhaustion (falls below the level of reserves); battery in exhaustion; memory alterations programming.

Isomed (Medtronic Italia, S.p.A., Rome, Italy) and Archimedes (Anschütz, Kiel, Germany) models are at constant flux (fig. 10), and hence at the refilling the daily concentration is attained modulating the refilling solution concentration, taking into account the daily flux ( 0,5 or $1 \mathrm{ml} /$ day).

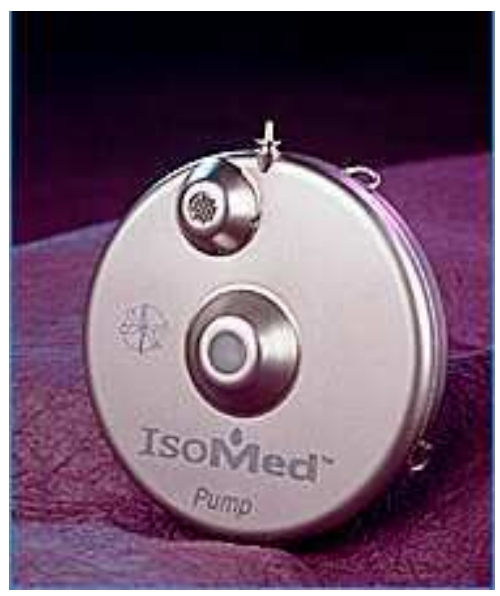

Fig. 10. Fixed flux infusion pump

Fixed flow pumps have a longer life by virtue of the absence of batteries, but are less precise than in the selection of the dose and can not afford the infusion of doses differentiated throughout the day, but for the change of dosage is required the emptying of the pump and filling with a new solution, to the dosage selected.

\section{Patient selection}

Careful patient selection is a fundamental factor for the positive outcome to the treatment. Intrathecal administration should be considered in patients who are unresponsive to treatment with oral opiates due to ineffective therapy or to intolerable side effects, who have good circulation of the cerebrospinal fluid and who possess a life expectancy of at least three months as diagnosed by the pain specialist and the oncologist.

Before beginning treatment, patients must pass a screening test which can be epidural or intrathecal. The intrathecal test is performed with single intrathecal injections of drug at L23 via a 27 Gauge Whitacre spinal needle (Becton Dickinson Caribe LTD. Juncos, PR), while patients is in prone position with a pillow under the chest, to keep the spine stretched. Agents used for this trial included either morphine $0,1 \mathrm{mg}$ and isobaric-bupivacaine $(0,5 \%)$ $0,125 \mathrm{mg}$, or saline solution $(2 \mathrm{ml})$ for the placebo test (3). This trial for efficacy and safety 
lasts usually 7 days. Placebo or morphine/bupivacaine IT injections are administered to patients on days 1, 3 and 7 of the trial. Patients are considered to be positive responders to IT analgesia if they have pain relief $>70 \%$ after administration of morphine and bupivacaine, and $<30 \%$ after injection of the placebo. The dosage of morphine/bupivacaine that provided relief of pain during the trial is the initial dose used after implantation.

If a patient does not respond optimally to the morphine, another test is carried out using a different opioid (e.g. hydromorphone, fentanyl, sufentanil); ziconotide or, depending on the type of pain, a combination of opiates + local anaesthetic (e.g. bupivacaine) or clonidine.

Patients responding positively to the test, the are programmed for implantation of the infusion system. Firstly a temporary implant is used, which includes a catheter implanted that is connected to an external pump CADD (Smiths-Medical Italia, S.r.l., Latina, Italy), which is programmable.

IT drug titration is performed as follows: the initial morphine dose is $0.1 \mathrm{mg} /$ day, in order to limit side effects, during the post-operative period, if the pain is not adequately controlled (Visual analogue scale, VAS $0-10$ reduction $<3$ points), the dosage is increased of $20 \%$ after 3-5 days. Then increments of $10 \%$ to $20 \%$ are used until pain is attenuated or intolerable side effects appear. When morphine dose is $0.5 \mathrm{mg} /$ day, then $0.5 \mathrm{mg} /$ day of bupivacaine is added to morphine infusion, if pain is still not controlled. The bupivacaine dose is then increased of $0.25 \mathrm{mgs} /$ day until a pain reduction $=3$ points in VAS (fig. 11). After two increases of bupivacaine dosage, if the VAS reduction is still $<3$ points, then the dosage of morphine is increased (max dosage $1.0 \mathrm{mg} /$ day) (76).

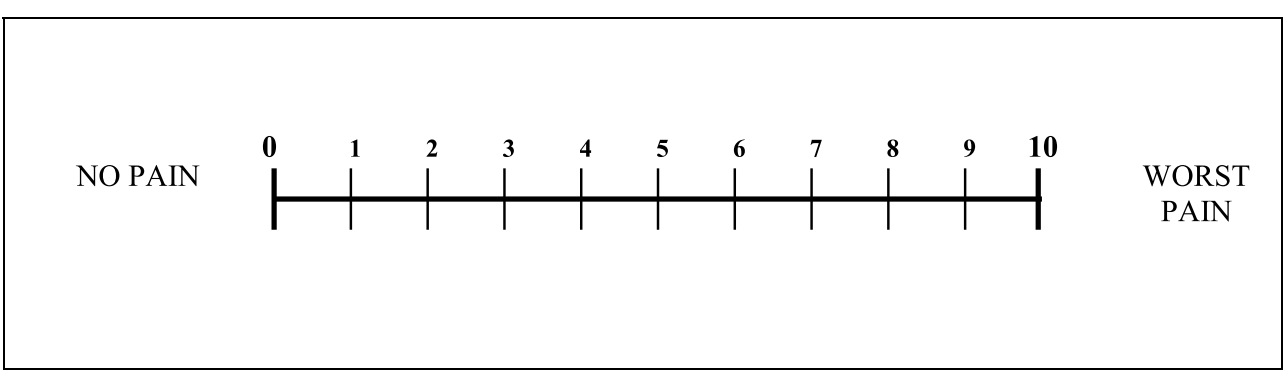

Fig. 11. VAS scale

When a optimal response is obtained (usually after 1-2 months), the permanent pump is implanted: after a precise preventive antibiotic therapy, and local anesthesia, the catheter, previously implanted, is connected to a pump that is inserted into a pocket under the skin, generally in the abdomen. The totally implanted pump is not visible outside and allows the subject to be free to move and make a normal life.

Management of patients throughout the various stages of the treatment should be based on a multidisciplinary approach involving psychologists, nurses, physiotherapists, social workers and spiritual advisors.

The selection criteria which characterize patients with cancer pain or non-malignant pain are similar. However, patients with non-malignant pain require a more comprehensive psychosocial assessment. 
Regarding the cost-effectiveness of intrathecal therapy for the treatment of pain, even though initial costs, associated with the surgical implant of an intrathecal pump, appear to be substantial; moreover the maintenance costs of intrathecal administration are significantly lower over time compared to other methods of delivery. In this way the overall cost of the therapy is reduced in the long term (21). Cost analysis of alternative methods (including oral) for the administration of opiates indicates that intrathecal treatment is more cost-effective in patients who require long-term management of cancer pain ( $\geq 3-6$ months) or non-malignant pain ( $\geq 11-22$ months).

\section{Risk associated with intrathecal administration}

Intrathecal administration of analgesic agents have some risks: specific drug-related sideeffects, medical complications (surgery), and technical complications related to the infusion device (77) (table 7, 8). Extremely dangerous are the complications related to pump delivery malfunctions, which may cause high dosage infusion or acute withdrawal (table 7), resulting in life-threatening side effects, such as coma or death.

\begin{tabular}{|c|c|}
\hline Postoperative complications & Instrumental Complications \\
\hline $\begin{array}{l}\text { - Infection of the pocket, the subcutaneous tunnel and the CSF } \\
\text { space } \\
\text { - CSF fistula, can be identified by the following symptoms: } \\
\text { headache gravitational, exacerbated the assumption of the } \\
\text { upright, sometimes associated with nausea, vertigo, tinnitus } \\
\text { and, rarely, diplopia due to the interest of the sixth cranial } \\
\text { nerve. The most serious complication of CSF fistulas is } \\
\text { represented by meningitis. } \\
\text { - Spinal tumors (granuloma), due to the retention of the } \\
\text { catheter into the subarachnoid space; } \\
\text { - Development of inflammatory mass at the tip of catheter, } \\
\text { which can cause serious neurological damage, including } \\
\text { paralysis. Symptoms: spinal cord compression, change in } \\
\text { intensity or type pain or contractions, onset of pain at the tip } \\
\text { of the catheter, need for continuous increases in dose, which } \\
\text { give only temporary relief. } \\
\text { - Hygroma of the pocket or a reflux of CSF resulting in } \\
\text { loosening and widening of the pocket } \\
\text { - Bruising, bleeding, swelling, serous pocket } \\
\text { - Headache due to loss of CSF during surgery } \\
\text { - Paralysis }\end{array}$ & 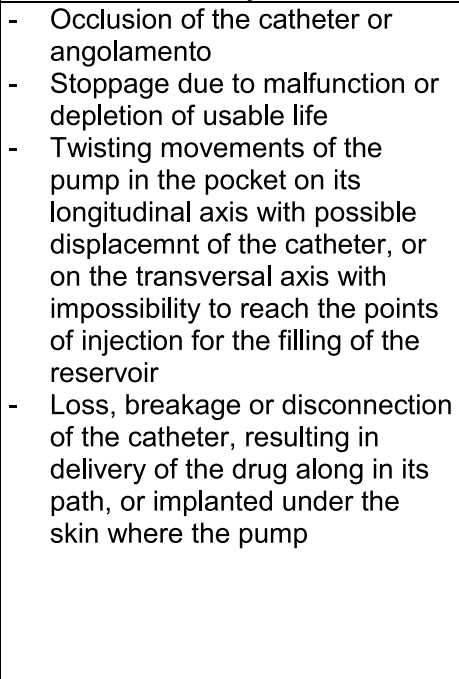 \\
\hline
\end{tabular}

Table 7. Complications of infusion pump

Withdrawal syndrome can also be observed if refilling is not performed inside the correct range of time, for this reason it is extremely important to refill the pump at least 2-3 days before the emptying of the reservoir. In any case of withdrawal a substitutive oral opioid therapy must be promptly started, while technical problems are solved.

Moreover, regarding cancer pain, there is a hesitancy to use invasive techniques by palliative care physicians in cancer patients at the end of life because their patients are often weak and suffering from frequent changes in painful pathology. In addition, there also is a low level of awareness of the procedures involved and a lack of professionals who are expert in the field. 


\begin{tabular}{|l|l|}
\hline Opioid Overdose Symptoms & Opioids Withdrawal symptoms \\
\hline$-\quad$ Respiratory depression & $-\quad$ yawn \\
$-\quad$ bradycardia & $-\quad$ runny nose \\
$-\quad$ Point miosis ("pinheads" pupil) & $-\quad$ piloerection \\
$-\quad$ Coma. & $-\quad$ Sweating \\
& $-\quad$ tearing \\
& $-\quad$ tremor \\
& $-\quad$ mydriasis \\
& $-\quad$ Cot flashes \\
& $-\quad$ restlessness \\
& $-\quad$ vomiting \\
& $-\quad$ Muscle spasms \\
& $-\quad$ Abdominal cramps \\
& $-\quad$ anxiety \\
\hline
\end{tabular}

Table 8. Drug-related complications of infusion pump

Anyway it is believed that the benefits of this method (table 6) could greatly outweigh the possible risks of implanting these devices and that prevention, early identification, and rapid management of the adverse effects, could allow for an optimal clinical outcome for the patients (77).

Intraoperative complications are extremely rare, and may be related to perforation of the dura mater that, given the calibre of the needle, can cause clinically significant CSF loss during the perioperative period, and require treatment with blood-patch and normal therapies indicated in such situations. Another complication is the bleeding into the epidural space, which can occur only if the patient has severe bleeding disorder, which is why blood tests are performed pre-operatively, to exclude patients with such problems. As concerning post operative complications, they are summarised in table 7 .

Sometimes experts in this spinal procedure dedicate insufficient attention to the interference between drugs (opioids) given and its effects on biological functions. Today, failure to understand the side-effects of intrathecal therapy by a implanting physician might be considered negligence, because it has been known for a long time that the use of opioids, for both acute and chronic pain, modifies the release of hypopituitary hormones and the activity of immune cells $(62,50)$. We believe that this spinal procedure should include clinical risk management and monitoring of hormonal function in all individuals (52).

\subsection{Drug-related side-effects}

The side effects associated with intrathecal administration of opiates or other analgesics are similar to those produced by systemic administration, but the delivery of extremely low 
doses means that the most important side effects (table 9), such as respiratory depression, are avoided or lessened (78).

\begin{tabular}{|c|c|}
\hline Short-term Opioid Adverse effects & Long-term Opioid Adverse effects \\
\hline $\begin{array}{l}\text { - } \text { Itching, } \\
\text { - Nausea, } \\
\text { - } \text { Vomiting, } \\
\text { - Diarrhea, } \\
\text { - } \text { Constipation, } \\
\text { - Drowsiness, } \\
\text { - Loss of appetite, } \\
\text { - } \text { Dry mouth, } \\
\text { - Dizziness, } \\
\text { - } \text { Hyperhidrosis, } \\
\text { - } \text { Urinary retention, } \\
\text { - } \text { Respiratory depression. }\end{array}$ & $\begin{array}{ll}\text { - } & \text { Nausea, } \\
\text { - } & \text { Vomiting, } \\
\text { - } & \text { Drowsiness, } \\
\text { - } & \text { Dry mouth, } \\
\text { - } & \text { Constipation, } \\
\text { - } & \text { Impotence, } \\
\text { - } & \text { Urinary retention, } \\
\text { - } & \text { Immunosuppression, } \\
\text { - } & \text { Interference with hormone levels } \\
& \text { (prolactin, growth hormone, thyroid } \\
& \text { hormone, adrenocorticotropic hormone } \\
& \text { and luteinizing hormone, testosterone), } \\
- & \text { Inhibition of the nociceptin, } \\
- & \text { Onset of tolerance (increased doses of } \\
& \text { opioids continuously). }\end{array}$ \\
\hline
\end{tabular}

Table 9. Opioid related adverse events

The most serious risk associated with intrathecal morphine was the development of respiratory depression, even if it is extremely rare, appearing in only $1 \%$ of cases. It can arise in the 3 to 16 hours following infusion. For this reason, patients need to be carefully monitored, above all in the 24 hours following infusion or a dose increase. Hyperalgesia, myoclonus, urinary retention, nausea, vomiting and itching are other side effects associated with the use of spinal opiates, above all in patients which require higher dosages.

Slow titration of the dosage, suitable prophylactic co-treatment and careful patient screening mean many of the side effects can be avoided. Management of the side effects associated with intrathecal administration of opiates involves reducing opiate doses, administering adjuvant drugs or, in serious cases, an opiate receptor antagonist. The side effects can be reduced by changing to another opiate (e.g. hydromorphone), or by combining bupivacaine or clonidine to a smaller dose of morphine.

There are dose-related effects to the use of bupivacaine. Side-effects such as paresthesia, motorsensory block, arterial hypotension, and urinary retention are associated with the anesthetic effects of bupivacaine at spinal levels, usually linked to daily doses above $45 \mathrm{mg}$ / day (79). The delivery of lower doses of bupivacaine means that these side-effects can be avoided or lessened. 
Slow titration of a given dose, suitable prophylactic pre-treatment and careful patient screening may mitigate many of these side-effects. Management of the side-effects associated with intrathecal administration of opioids involves reducing opioid-doses, administering adjuvant medications or, in serious cases, an opioid-receptor antagonist. The side-effects also can be reduced by changing to another opioid as in opioid rotation (e.g., hydromorphone), or by combining bupivacaine or clonidine to a smaller dose of the opioid infused.

\subsection{Opioid: Addiction and tolerance}

One of the worst risks associated to the opioid use is the rise of tolerance and addiction. Drug addiction is a constant psychological and physical craving for legal or illegal substances, even in the face of adverse consequences, according to the National Institute on Drug Abuse. Drug addiction is a disease, because drug abuse causes changes in brain chemistry that make it difficult to function without the substance of choice; however, like diabetes and heart disease, it can be managed with proper intervention. Biology, genetic development and living environment may all play a role in why some people become addicts and other users do not.

The term "addiction" is often applied to two phenomena, one psychological, the other physical, which must be clearly distinguished from each other $(80,81)$. On one hand there is the irresistible urge to take the drug, on the other the sudden deprivation syndrome, both depending by the drug intake in the organism. The neuro-anatomical substrates of these two phenomena appear distinct. Bulbar and mesencephalic structures, particularly the Locus Coeruleus, the Raphe Nucleus and Periaqueductal gray matter, are involved in the event of the withdrawal syndrome. Limbic territories (Ventral Nidbrain, Ventral Striatum, Hippocampus, Amygdala, etc) are involved mainly in the persistent desire for opioids and in the mechanism of addiction that they generate. The mesolimbic dopaminergic system plays a central role, as it is involved in both the euphoric effects of opioids, both in the modulation of neuronal circuits, which are directly responsible of the withdrawal symptom (82).

Repeated administration of opioids can result in the development of tolerance, which can be defined as the rightward shift of the dose response curve for a substance. The associative tolerance is related to conditioning, while the so-called pharmacological tolerance is due to the mechanism of action of the drug. The pharmacological tolerance may be due to constitutional factors, changes in pharmacokinetic or, more frequently, due to decreased pharmacodynamic effects of analgesic related to some process of neural adaptation.

These processes are characterized by great variability intra- and interpatient. Tolerance to different effects of opioids develops at different speeds and can occur quickly after acute administration or develop more gradually as the recurrence of the hiring $(83,84)$. Development of tolerance can be maintained during long-term administration or appear and progress quickly in the first phase of treatment.

Opioids exert their actions via membrane receptors which are coupled to their effectors by G protein. Scientist tried to find out whether these alterations are involved in the different elements of tolerance and dependence. Probably changes in the number and/or affinity of opioid receptors for their ligands are mechanisms that are not involved. In fact, when these changes are eventually found, tolerance and dependence have already developed; therefore, alterations of receptors would rather be the consequences and not the cause of tolerance and 
dependence. On the other hand, a functional coupling between opioid receptors and their effectors is probably one of the mechanisms involved in the development of tolerance to morphinomimetics, despite the interaction mechanism is still not clearly established (83).

Recently an imbalance between the excitatory and inhibitory effects of opioids was suggested. In fact, in addition to classical receptors responsible for the actions of opioids, whose stimulation causes inhibitory effects that result in a hyperpolarization of neurons and a reduction of the release of neurotransmitters, there are opioid receptors whose stimulation has the opposite excitatory effect. Agonists have a much greater affinity for these excitatory receptors than for the inhibitory ones (85). In other words, the effect of the stimulation on opioid receptors, including their analgesic action (86), it would be the result of: the exciter action connected to the involvement of higher-affinity receptors for the agonists; and of the inhibitory action due to lower-affinity receptors stimulation (87). Chronic treatment with opioids results in a reduction of its inhibitory influence and a hypersensitivity to its action exciter $(88,89)$. It is believed that these alterations may be involved in the development of tolerance to the inhibitory effects of opioids and in the manifestations of withdrawal syndrome.

The morphinomimetics influence the activity of neurons that have opioid receptors and a number of neurons networks are involved in a given pharmacological effect of these substances. Many neuronal central regions and almost all neurotransmitters, such as dopamine, norepinephrine, serotonin, acetylcholine and GABA (90), are implicated in the onset or expression of different manifestations of tolerance and/or morphine addiction. Recently the role of excitatory amino acids (EAA) was emphasised, in fact, blocking some EAA receptors (NMDA) inhibits the development of tolerance to the analgesic effects of morphine (80).

Some of the target neurons of morphinomimetics could be part of a homeostatic system that tends to reduce the action of opioids. Thus opioids would activate neurons which would release neuropeptides, that act as antagonists of endogenous opioids. The hyperactivity of neurons to cholecystokinin-8 (CCK-8) and to neuropeptide FF (NPFF), induced by prolonged administration of morphine, is partly the cause of drug tolerance and addiction (91).

The different hypotheses are not mutually exclusive; it is likely that these different mechanisms contribute to the appearance of tolerance and dependence in different ways and degrees. Tolerance develops as a result of spinal administration of opioids, although it seems to grow more slowly and in a reduced way than the use of systemic opioids (92).

\section{Guidelines to threat patiens intrathecally}

Management of patients throughout the various stages of the diagnosis and treatment of pain should be based on multidisciplinary expertise. Careful patient selection is the one fundamental factor accounting for positive outcomes to treatment.

These are the suggested criteria for patients receiving intrathecal therapy:

- Intrathecal administration should be reserved for patients who are unresponsive or poorly responsive to treatment with oral / transdermal opioids, either because of the development of tolerance, in spite of sequential drug trialing, or because of the development of dose-specific side-effects. 
- The selection criteria for patients with cancer pain or noncancer pain are similar. However, patients with noncancer pain, because of their life expectancy, should require a more comprehensive sychosocial assessment.

- A psychosocial evaluation should explore:

1. patients' expectations of their therapy,

2. analyze the quality of the patient's pain and the meaning of the pain to the patient,

3. the presence of psychologic disease that might prevent adequate outcomes to the therapy, and

4. barriers to patient and family compliance to the use of the pump system.

- No pathology on cerebrospinal fluid found.

- Informed consent to the procedure.

\section{Step no. 1}

A temporary trial of spinal opioid therapy should be performed to assess the potential benefits of this approach before implantation. In order to be considered an ideal candidate for intrathecal administration, a patient must demonstrate a reduction in pain of at least $50 \%$ with the observable absence of intolerable side-effects from the agent tested. Morphine should be the first agent trialed because more is known about morphine than any other agent. If a patient does not respond optimally to morphine, an another agent should be trialed such as hydromorphone, fentanyl, sufentanil, or, depending on the type of pain, as in neuropahtic pain, a combination of opioids and local anesthetic (e.g., bupivacaine). Many differing methods for this trial have been reported, such as the continuous epidural or intrathecal infusion of agents or single shot injections of these agents, either epidural or intrathecal $(93,94)$.

\section{Step no. 2}

After a successful trial and once the pump has been implanted, the initial daily dose of morphine or agent found to be the best at trial should be that dose that gave the most efficacious response at the time of trial. In an effort to limit side-effects during the initial postoperative therapy period, an intrathecal morphine dose, that is $20 \%$ lower than the screening test dose, should be used. The initial dose should be increased, if necessary, by $20 \%$ every 3-5 days until the dose used at trial is reached. After that dose has been reached, increases in dose should be by increments of no more that $10 \%$ to $20 \%$ until pain control is reached or until intolerable side-effects appear.

\section{Monitoring}

Patients with implanted drug delivery systems must be monitored at regular intervals of time. Monitoring for efficacy and side-effects, especially those due to perturbations of the endocrine system, is good medicine and standard of care.

Anyway a clear standard for the correlation of a specific combination of drugs to the treatment of a specific type of pain is still lacking. An effective dose of opioids is variable and individual to the needs of each and every patient; however, the effective dose of any one opioid often reaches high levels for various reasons including syndromespecific opioid resistance, receptor phenotype-determined resistance, and/or tolerance to the opioid delivered. Appropriate patients are selected for Intrathecal Drug Delivery System using IT / epidural trials either by single shot injection or titration through an implanted catheter until effective dosage is reached (33). 


\section{IT in geriatric population}

The IT administration of low-dose agents for the attainment of satisfactory pain control is particularly important for the geriatric population. Nowadays, the number of elderly people and the average age of the population are increasing. The elderly often suffer from agerelated diseases such as vascular cardiopathies, cerebrovascular diseases, osteoporosis, and arthrosis, which are, in-ofthemselves, themselves allergenic (95) and from pneumonias, diabetes, peripheral arterial diseases, and fractures, which generate further pain (96). These diseases result in serious disabilities and limitation of patients' physical, cognitive, and social activities, resulting in loss of the autonomy and worsening of their quality of life. For this reason, it is of primary importance to find an efficient analgesic therapy for the elderly that avoids pharmacologic interactions with other medications used by patients for the treatment of their comorbid diseases that result in unwanted effects and adverse events. It is also well established that the elderly (older than 64 years) need lower doses of drugs to achieve the same level of efficacy that younger patients need. The aging process, indeed, involves a series of metabolic modifications that result in important alterations of the pharmacokinetics and dynamics of a drug (97). In particular, the reduction of body water level results in a reduced distribution of hydrophilic drugs, such as morphine. Similarly, the agerelated reduction of plasma proteins causes an increase in the concentration of active drug and, hence, a reduction in drug dosage needed. Moreover, the decrease of renal and hepatic output requires an adjustment of drug dosages given to the elderly $(98,99)$.

\section{Future work}

Intrathecal pump implantation has its advantages and its advantages; the main concern is if the elimination of systemic side-effects justifies an invasive procedure with its own potential serious complications. The costs of the device is high, however, it is cost-effective in the long term in patients responding to this treatment (100).

From the literature, actually, there is no solid outcome evidence that supports intrathecal therapy use, indeed, randomized studies are still scarce, and in several studies the number of patients is low.

Despite the fact that opioids and morphine in particular are the most used intrathecal drug, ziconotide is increasingly used for intrathecal therapy. It has also been recently indicated as first line IT drug by the Polyanalgesic Consensus Conference (45), thanks to its property and efficacy (101-104), and it is extremely useful also for patients intolerant or refractory to the common IT drugs (such as morphine).

Our recent work shows that ziconotide has good levels of efficacy and long-term safety, which can be attained at stable doses with a constant pain relief, suggesting the absence of tolerance effects (104). This suggests, moreover, that, once the early side effects are overcome, the responders are not exposed to long-term risks.

We believe that this drug has a great potential for future IT therapy, in order to reduce common long-term opioid related adverse events: immunomodulation, influence on the endocrine system and tolerance.

IT therapy, moreover is useful also for the treatment of spasticity: baclofen is widely applied for this purpose (105-108), alone or in association with ziconotide, or local anesthetics, in cases of spasticity associated with pain $(73,108)$. 


\section{Conclusion}

Intrathecal administration of drugs by qualified personnel significantly enhances pain relief and improves the quality of life in patients who fail conservative therapies with oral or transdermal delivery of analgesics, while reducing the risk of adverse effects and complications. According to indications suggested by the International Consensus Conference (17), that took place in Belgium in 1998, the fundamental prerequisite for the correct application of intrathecal therapy with opioids is appropriate professional training regarding: catheter and pump implant procedures; knowledge of the anatomy, physiology, and neuropharmacology of the neuromodulatory centers of the spinal cord and the brain; knowledge of systemic complications; a multidisciplinary approach to care.

However, because the literature is bereft of good clinical science that pertains to intrathecal therapy and is full of anecdotal material, we believe that long-term prospective and randomized studies are necessary to fully evaluate the safety and efficacy of the intrathecal administration of opioids and nonopioids alike for pain relief. It is important that these prospective, randomized, controlled trials identify not only the efficacy of intrathecal to provide pain management, but also the biological impact that the route of administration of analgesics (systemic vs. intrathecal) has on the general health and well-being of the patient.

\section{References}

[1] Merskey H, Bogduk N. Classification of Chronic Pain. Seattle: IASP Press; 1994:210.

[2] Shaladi AM, Saltari MR, Crestani F, Piva B. Post-surgical neuropathic pain. Recenti Prog Med 2009;100(7-8):371-9.

[3] Raffaeli W, Marconi G, Fanelli G, Taddei S, Borghi GB, Casati A. Opioid-related sideeffects after intrathecal morphine: a prospective, randomized, double-blind doseresponce study. European Journal of Anaesthesiology 2006, 23: 605-610.

[4] Hassenbusch SJ, Paice JA, Patt RB, Bedder MD, Bell GK. Clinical realities and conomic considerations: efficacy of intrathecal pain therapy. J Pain Symptom Manage 1997;14 (Suppl.):S14-S26.

[5] World Health Organization Programme on Cancer Control. Developing a global strategy for cancer. Editor: Karol Sikora, March 1998.

[6] World Health Organization. Cancer pain relief. Geneva, Switzerland: WHO, 1986.

[7] World Health Organization. Achieving balance in national opioids control policy: guidelines for assessment. Geneva, Switzerland: WHO, 2000.

[8] World Health Organization. Cancer pain relief and palliative care: Report of a WHO expert committee (Technical Report Series 804). Geneva, Switzerland: WHO, 1990.

[9] Foley KM. Controversies in cancer pain: medical perspectives. Cancer 1989;63:2257-2265.

[10] Schug SA, Zech D, Don U. Cancer pain management according to WHO analgesic guidelines. J Pain Symptom Manage 1990;5:27-32.

[11] Zech DFJ, Grond S, Lynch J, Hertel D, Lehmann KA. Validation of World HeaIth Organization Guidelines for cancer pain relief: a 10-year prospective study. Pain 1995;63:65-76.

[12] Mercadante $S$ et al. Episodic (breakthrough) pain. Consensus Conference of an expert working group of the European Association for Palliative Care. Cancer 2002.

[13] Gardner-Nix J. Oral transmucosal fentanyl and sufentanyl for incident pain. J Pain Symptom Manage 2001;22:627. 
[14] Catala E. Intrathecal administration of opioids in cancer patients. Paper presented at a satellite symposium of the European Federation of IASP Chapters Second Congress, September 22-23, 1997, Barcelona, Spain.

[15] Vargas-Schaffer G. Is the WHO analgesic ladder still valid? Twenty-four years of experience. Can Fam Physician;56(6):514-7, e202-5.

[16] Wang JF, Nauss LA, Thomas JE. Pain relief by intrathecally applied morphine in man. Anesthesiology 1979;50:149-151.

[17] Coombs DW, Saunders RL, Gaylor MS, Pageau MG, Leith MG, Schaiberger C. Continuous epidural analgesia via implanted morphine reservoir. Lancet 1981; 2: 425-426.

[18] Kwan JW. Use of infusion devices for epidural or intrathecal administration of spinal opioids. Am J Hosp Pharm 1990;47 (Suppl. 1):S18-S23.

[19] Yaksh TL, Rudy TA. Analgesia mediated by a direct spinal action of narcotics. Science 1976;192(4246):1357-8.

[20] Smith HS, Deer TR, Staats PS, Singh V, Sehgal N, Cordner H. Intrathecal drug delivery. Pain Physician 2008;11(2 Suppl):S89-S104.

[21] Portenoy RK. Clinical realities and economic considerations: introduction. J Pain Symptom Manage 1997;14 (Suppl.):SI-S2.

[22] Task Force of the European Federation of IASP Chapters (EFIC). Neuromodulation of pain: a consensus statement prepared in Brussels 16-18 January. Eur J Pain 1998;2:203-209.

[23] Krames ES, Olson K. Clinical realities and economic considerations: patient selection in intrathecaI therapy. J Pain Symptom Manage 1997;14 (Suppl.): S3-S13.

[24] Bennett G, Serafini M, Burchiel K, Buchser E, Classen A, Deer T, et al. Evidence-based review of the literature on intrathecal delivery of pain medication. J Pain Symptom Manage 2000;20(2):S12-36.

[25] Deer T, Winkelmuller W, Erdine S, Bedder M, Burchiel K. Intrathecal therapy for cancer and nonmalignant pain: patient selection and patient management. Neuromodulation 1999;2(2):55-66.

[26] Stain F, Barjavel MJ, Sandouk P, Plotkine M, Scherrmann JM, Bhargava HN. Analgesic response and plasma and brain extracellular fluid pharmacokinetics of morphine and morphine-6-beta-D-glucuronide in the rat. J Pharmacol Exp Ther 1995;274(2):852-7.

[27] Krames E. The chronic intraspinal use of opioid and local anesthetic mixtures for the relief of intractable pain: when all else fails! Pain 1993;55:1-4.

[28] Nordberg G, Hedner T, Mellstrand T, Dahlstrom B. Pharmacokinetic aspects of intrathecal morphine analgesia. Anesthesiology 1984;60:448-454.

[29] Sullivan ARF, McQuay HJ, Bailey D, Dickenson AH. The spinal antinociceptive actions of morphine metabolites: morphine-6-glucuronide and normorphine in the rat. Brain Res 1989; 482:219-224.

[30] Sandouk P, Serrie A, Scherrmann JM, Langlade A, Bourre JM. Presence of morphine metabolites in human cerebrospinal fluid after intracerebroventricular administration of morphine. Eur J Drug Metab Pharmacokinet 1991;Spec No 3:166-71.

[31] McQuay HJ, Sullivan AF, Smallman K, Dickenson AH. Intrathecal opioids, potency and lipophilicity. Pain 1989;36(1):111-5. 
[32] Sullivan AF, McQuay HJ, Bailey D, Dickenson AH. The spinal antinociceptive actions of morphine metabolites morphine-6-glucuronide and normorphine in the rat. Brain Res 1989;482(2):219-2

[33] Georges P, Lavand'homme P. Intrathecal hydromorphone instead of the old intrathecal morphine: the best is the enemy of the good? Eur J Anaesthesiol;2012, 29(1):3-4.

[34] Wallace M, Yaksh TL. Long-term spinal analgesic delivery: a review of the preclinical and clinical literature. Reg Anesth Pain Med 2000;25:117-157.

[35] Li DF, Bahar M, Cole G, Rosen M. Neurological toxicity of the subarachnoid infusion of bupivacaine, lignocaine or 2-chloroprocaine in the rat. Br J Anaesth 1985;57:424-429.

[36] Dahm P, Nitescu P, Appelgren L, Curelaru I. Efficacy and technical complications of long-term continuous intraspinal infusions of opioid and/or bupivacaine in refractory nonmalignant pain: a comparison between the epidural and the intrathecal approach with externalized or implanted catheters and infusion pumps. Clin J Pain 1998;14:4-16.

[37] Van Dongen RT, Crul BJ, van Egmond J. Intrathecal coadministration of bupivacaine diminishes morphine dose progression during long-term intrathecal infusion in cancer patients. Clin J Pain 1999;15:166-172.

[38] Franco Gay ML. Spinal morphine in nonmalignant chronic pain: a retrospective study in 39 patients. Neuromodulation 2002;5:150-159.

[39] Eisenach J, DuPen S, Dubois M, Miguel R, Allin D. Epidural clonidine analgesia for intractable cancer pain. Pain 1995;61:391-399.

[40] Yaksh T. Pharmacology of spinal adrenergic systems which modulate spinal nociceptive processing. Pharmacol Biochem Behav 1985;22:845-858.

[41] Levy R, Leiphart J, Dills C. Analgesic action of acute and chronic intraspinally administered opioid and alph6 agonists in chronic neuropathic pain. Stereotact Funct Neurosurg 1994;62:279-289.

[42] Krames ES, Lanning RM. Intrathecal infusional analgesia for nonmalignant pain: analgesic efficacy of intrathecal opioid with or without bupivacaine. J Pain Symptom Manage 1993;8:539-548.

[43] Sjoberg M, Appelgreen L, Einarsson S et al. Long-term intrathecal morphine and bupivacaine in refractory cancer pain. I. Results from the first series of 52 patients. Acta Anaesthesiol Scand 1991;35:30-43.

[44] Hassenbusch SJ, Portenoy RK. Current practices in intraspinal therapy - a survey of clinical trends and decision making. J Pain Symptom Manage 2000;20:4-11.

[45] Deer T, Krames ES, Hassenbusch SJ, Burton A, Caraway D, Dupen S, Eisenach J, Erdek M, Grigsby E, Kim P, Levy R, McDowell G, Mekhail N, Panchal S, Prager J, Rauck R, Saulino M, Sitzman, T, Staats P, Stanton-Hicks M, Stearns L, Willis KD, Witt W, Follett K, Huntoon M, Liem L, Rathmell J, Wallace M, Buchser. E, Cousins M, Ver Donck A. Polyanalgesic consensus conference 2007: recommendations for the management of pain by intrathecal (intraspinal) drug delivery: report of an interdisciplinary expert panel. Neuromodulation 2007;10(4):300-28.

[46] Lara NA, Jr., Teixeira MJ, Fonoff ET. Long term intrathecal infusion of opiates for treatment of failed back surgery syndrome. Acta Neurochir Suppl; 2011,108:41-7.

[47] Brazenor GA. Long term intrathecal administration of morphine: a comparison of bolus injection via reservoir with continuous infusion by implanted pump. Neurosurgery 1987;21(4):484-91. 
[48] Gourlay GK, Plummer JL, Cherry DA, Onley MM, Parish KA, Wood MM, et al. Comparison of intermittent bolus with continuous infusion of epidural morphine in the treatment of severe cancer pain. Pain 1991;47(2):135-40.

[49] Trescot AM, Datta S, Lee M, Hansen H. Opioid pharmacology. Pain Physician 2008;11(2 Suppl):S133-53.

[50] Raffaelli W, Salmosky-Dekel BG. Biological consequences of long-term intrathecal administration of opioids. Minerva Anestesiol 2005;71(7-8):475-8.

[51] Campana G, Sarti D, Spampinato S, Raffaeli W. Long-term intrathecal morphine and bupivacaine upregulate MOR gene expression in lymphocytes. Int Immunopharmacol; 2010,10(9):1149-52.

[52] Raffaeli W, Salmosky-Dekel B.G, Rita M, Righetti D, Caminiti A, Balestri M, Sarti D, Fanelli G. Long-term intrathecal morphine influence on major compounds of the endocrine system in elderly population. Eur J of Pain Suppl,2009;3:71-76

[53] Kellum JA. The modern concept of homeostasis. Minerva Anestesiol 2002;68:3-11.

[54] Vallejo R, Leon-Casasola O, Benyamin R. Opioid therapy and immunosuppression: a review. Am J Ther 2004;11:354-65.

[55] Mathews PM, Froelich CJ, Sibbitt WL Jr, Bankhurst AD. Enhancement of natural cytotoxicity by beta-endorphin. J Immunol 1983;130:1658-62.

[56] Dimitrijevic M, Stanojevic S, Kovacevic-Jovanovic V, Miletic T, Vujic-Redzic V, Radulovic J. Modulation of humoral immune responses in the rat by centrally applied Met-Enk and opioid receptor antagonists: functional interactions of brain OP1, OP2 and OP3 receptors. Immunopharmacology 2000;49:255-62.

[57] Jankovic BD, Veljic J, Pesic G, Maric D. Enkephalinaseinhibitors modulate immune responses. Int J Neurosci 1991;59:45-51.

[58] Radulovic J, Jankovic BD. Opposing activities of brain opioid receptors in the regulation of humoral and cellmediated immune responses in the rat. Brain Res 1994;661:189-95.

[59] Radulovic J, Miljevic C, Djergovic D, Vujic V, Antic J, Von Horsten S, et al. Opioid receptor-mediated suppression of humoral immune response in vivo and in vitro: involvement of kappa opioid receptors. J Neuroimmunol 1995;57:55-62.

[60] Veljic J, Ranin J, Maric D, Jankovic BD. Modulation of cutaneous immune reactions by centrally applied methionine-enkephalin. Ann N Y Acad Sci 1992;650:51-5.

[61] Mellon RD, Bayer BM. Evidence for central opioid receptors in the immunomodulatory effects of morphine: review of potential mechanism(s) of action. J Neuroimmunol 1998;83:19-28.

[62] Provinciali M, Raffaeli W. Evaluation of NK and LAK cell activities in neoplastic patients during treatment with morphine. Intern J Neuroscience 1991;59:127-33.

[63] Morley JE. The endocrinology of the opiates and opioid peptides. Metabolism 1981;30:195-209.

[64] Su CF, Liu MY, Lin MT. Intraventricular morphine produces pain relief, hypothermia, hyperglycaemia and increased prolactin and growth hormone levels in patients with cancer pain. J Neurol 1987;235:105-8.

[65] Rasmussen DD, Liu JH, Wolf PL, Yen SS. Endogenous opioid regulation of gonadotropin-releasing hormone release from the human fetal hypothalamus in vitro. J Clin Endocrinol Metab 1983;57:881-4.

[66] Delitala G, Devilla L, Musso NR. On the role of dopamine receptors in the naloxoneinduced hormonal changes in man. J Clin Endocrinol Metab 1983;56:181-4. 
[67] Grossman A, Moult PJ, Cunnah D, Besser M. Different opioid mechanisms are involved in the modulation of ACTH and gonadotrophin release in man. Neuroendocrinology 1986;42:357-60.

[68] Gold PW, Extein I, Pickar D, Rebar R, Ross R, Goodwin FK. Supression of plasma cortisol in depressed patients by acute intravenous methadone infusion. Am J Psychiatry 1980;137:862-3.

[69] Abs R, Verhelst J, Maeyaert J, Van Buyten JP, Opsoner F, Adriaensen H, et al. Endocrine consequences of long-term intrathecal administration of opioids. J Clin Endocrinol Metab 2000;85:2215-22.

[70] Paice JA, Penn RD, Ryan WG. Altered sexual function and decreased testosterone in patients receiving intraspinal opioids. J Pain Symptom Manage 1994;9:126-31.

[71] Roberts LJ, Finch PM, Pullan PT, Bhagat CI, Price LM. Sex hormone suppression by intrathecal opioids: a prospective study. Clin J Pain 2002;18:144-8.

[72] Patel VB, Manchikanti L, Singh V, Schultz DM, Hayek SM, Smith HS. Systematic review of intrathecal infusion systems for long-term management of chronic non-cancer pain. Pain Physician 2009;12(2):345-60.

[73] Smith HS, Deer TR, Staats PS, Singh V, Sehgal N, Cordner H. Intrathecal drug delivery. Pain Physician 2008;11(2 Suppl):S89-S104.

[74] Anderson VC, Burchiel KJ. A prospective study of long-term intrathecal morphine in the management of chronic nonmalignant pain. Neurosurgery 1999;44(2):289-300; discussion 300-1.

[75] Smith TJ, Staats PS, Deer T, Stearns LJ, Rauck RL, Boortz-Marx RL, et al. Randomized clinical trial of an implantable drug delivery system compared with comprehensive medical management for refractory cancer pain: impact on pain, drug-related toxicity, and survival. J Clin Oncol 2002;20(19):4040-9.

[76] Raffaeli W, Righetti D, Caminiti A, Ingardia A, Balestri M, Pambianco L, Fanelli G, Facondini F, Pantazopoulos P. Implantable Intrathecal Pumps for the Treatment of Noncancer Chronic Pain in Elderly Population: Drug Dose and Clinical Efficacy. Neuromodulation 2008; 11 (1): 33-39.

[77] Naumann C, Erdine S, Koulousakis A, Van Buyten JP, Schuchard M. Drug adverse events and systemic complications of intrathecal opioid delivery for pain: origins, detection, manifestations, and management. Neuromodulation 1999;2(2):92-107.

[78] Lamer TJ. Treatment of cancer-related pain: when orally administered medications fail. Mayo Clin Proc 1994;69:473-480.

[79] Sjöberg M, Nitescu P, Appelgren L, Curelaru I. Long-term intrathecal morphine and bupivacaine in patients with refractory cancer pain: results from a morphine: bupivacaine dose regimen of 0.5: $4.75 \mathrm{mg} / \mathrm{mL}$. Anesthesiology 1994; 80:284-297.

[80] Trujillo KA, Akil H. Opiate tolerance and dependence: recent findings and synthesis. New Biologist 1991;3:915-923.

[81] Stolerman I. Drugs of abuse: behavioural principles, methods and terms. Trends Pharmacol Sci 1992;13:170-176.

[82] Harris GC, Aston-Jones G. Involvement of D2 dopamine receptors in the nucleus accumbens in the opiate withdrawal syndrome. Nature 1994;371:155-7.

[83] Collin E, Cesselin F. Neurobiological mechanisms of opioid tolerance and dependence. Clin Pharmacol 1991;14:465-488.

[84] Portenoy RK. Tolerance to opioid analgesics: clinical aspects. Cancer Surveys 1995;21:49-65. 
[85] Crain SM, Shen KF. Opioids can evoke direct receptor-mediate excitatory effects on sensory neurons. Trends Pharmacol Sci 1990;11:77-81.

[86] Shen KF, Crain SM. Antagonists at excitatory opioid receptors on sensory neurons in culture increase potency and specificity of opiate analgesics and attenuate development of tolerance/dependence. Brain Res. 1994 Feb 14;636(2):286-97.

[87] Cruciani RA, Dvorkin B, Morris SA, Crain SM, Makman MH. Direct coupling of opioid receptors to both stimulatory and inhibitory guanine nucleotide-binding proteins in F-11 neuroblastoma-sensory neuron hybrid cells. Proc Natl Acad Sci U S A. 1993 Apr 1;90(7):3019-23.

[88] Crain SM, Shen KF, Chalazonitis A. Opioids excite rather than inhibit sensory neurons after chronic opioid exposure of spinal cord-ganglion cultures. Brain Res. 1988 Jul 5;455(1):99-109.

[89] Gintzler AR, Chan WC, Glass J. Evoked release of methionine enkephalin from tolerant/dependent enteric ganglia: paradoxical dependence on morphine. Proc Natl Acad Sci U S A. 1987 Apr;84(8):2537-9.

[90] Redmond DE Jr, Krystal JH. Multiple mechanisms of withdrawal from opioid drugs. Annu Rev Neurosci. 1984;7:443-78.

[91] Cesselin F. Opioid and anti-opioid peptides. Fundam Clin Pharmacol. 1995;9(5):409-33.

[92] Sabbe MB, Yaksh TL. Pharmacology of spinal opioids. J Pain Symptom Manage. 1990 Jun;5(3):191-203.

[93] Krames ES. Intraspinal opioid therapy for chronic nonmalignant pain: current practice and clinical guidelines. J Pain Symptom Manage 1996;11:333-352.

[94] Krames ES. Intrathecal infusional therapies for intractable pain: patient management guidelines.J Pain Symptom Manage 1993;8:36-46.

[95] Brody JA, Schneider EL. Age dependent and age related disease. J Chronic Dis 1956;39:11-871.

[96] Chodosh J, Solomon D, Roth OP. The quality of medical care provided to vulnerable older patients with chronic pain. J Am Geriatr Soc 2004;52:756-771.

[97] Holford NHG, Sheiner LB. Pharmacokinetic and dynamic modelling in vivo. CRC Crit Rev Bioeng 1981;5:273-322.

[98] Moffat JA, Milne B. pharmacokinetics in anaesthesia. Can Anaesth Soc J 1983;30:300307.

[99] Hilgenberg JC. Inhalation and intravenous drugs in the elderly patient. Semin Anesth 1986;5:44-53.

[100] Anderson VC, Cooke B, Burchiel KJ. Intrathecal hydromorphone for chronic nonmalignant pain: a retrospective study. Pain Med. 2001;2:287-97.

[101] Staats PS, Yearwood T, Charapata SG, et al. Intrathecal ziconotide in the treatment of refractory pain in patients with cancer or AIDS: a randomized controlled trial. JAMA. 2004;291:63-70

[102] Wallace MS, Charapata SG, Fisher R, et al. Intrathecal ziconotide in the treatment of chronic nonmalignant pain: a randomized, double-blind, placebo-controlled clinical trial. Neuromodulation. 2006;9:75-86

[103] Rauck RL, Wallace MS, Leong MS, et al. A randomized, double-blind, placebocontrolled study of intrathecal ziconotide in adults with severe chronic pain. J Pain Symptom Manage. 2006;31:393-406 
[104] Raffaeli W, Sarti D, Demartini L, Sotgiu A, Bonezzi C; Italian Ziconotide Group. Italian registry on long-term intrathecal ziconotide treatment. Pain Physician. 2011 JanFeb;14(1):15-24.

[105] Ucar T, Kazan S, Turgut U, Samanci NK. Outcomes of intrathecal baclofen (ITB) therapy in spacticity. Turk Neurosurg. 2011 Jan;21(1):59-65.

[106] Haranhalli N, Anand D, Wisoff JH, Harter DH, Weiner HL, Blate M, Roth J. Intrathecal baclofen therapy: complication avoidance and management. Childs Nerv Syst. 2011;27(3):421-7.

[107] Saval A, Chiodo AE. Intrathecal baclofen for spasticity management: a comparative analysis of spasticity of spinal vs cortical origin. J Spinal Cord Med. 2010;33(1):16

[108] Carrillo-Ruiz JD, Andrade P, Godínez-Cubillos N, Montes-Castillo ML, Jiménez F, Velasco AL, Castro G, Velasco F. Coupled obturator neurotomies and lidocaine intrathecal infusion to treat bilateral adductor spasticity and drug-refractory pain. J Neurosurg. 2010;113(3):528-31.

[109] Raffaeli W, Andruccioli J, Righetti D, Caminiti A, Balestri M. Intraspinal therapy for the treatment of chronic pain: a review of the literature between 1990 and 2005 and suggested protocol for its rational and safe use. Neuromodulation. 2006;9(4):290-308.

[110] Van Dongen RTM et al. Intrathecal coadministration of bupivacaine diminishes morphine dose progression during long-term intrathecal infusion in cancer patients. The Clinical Journal of Pain 1999;15:166-172.

[111] Smith TJ, Staats PS, Deer T, Stearns LJ, Rauck RL, Boortz-Marx RL, Buchser E, Catala E, Bryce DA, Coyne PJ, Pool GE. Randomized clinical trial of an implantable drug delivery system compared with comprehensive medical management for refractory cancer pain: impact on pain, drug-related toxicity, and survival. J Clin Oncol 2002;20(19):4040-9.

[112] Rauck RL, Cherry D, Boyer MF, Kosek P, Dunn J, Alo K. Long-term intrathecal opioid therapy with a patient-activated, implanted delivery system for the treatment of refractory cancer pain. J Pain 2003;4(8):441-7.

[113] Smith TJ, Coyne PJ, Staats PS, Deer T, Stearns LJ, Rauck RL, et al. An implantable drug delivery system (IDDS) for refractory cancer pain provides sustained pain control, less drug-related toxicity, and possibly better survival compared with comprehensive medical management (CMM). Ann Oncol 2005;16(5):825-33.

[114] Willis KD, Doleys DM. The effects of long-term intraspinal infusion therapy with noncancer pain patients: evaluation of patients, significant-other and clinic staff appraisals. Neuromodulation 1999;2:241-253.

[115] Brown J, Klapow J, Doleys D, Lowery D, Tutak U. Disease-specific and generic health outcomes: a model for the evaluation of long-term intrathecal opioid therapy in noncancer low back pain patients. Clin J Pain 1999;15(2)122-31.

[116] Roberts LJ, Finch PM, Goucke CR, Price LM. Outcome of intrathecal opioids in chronic non-cancer pain. Eur J Pain 2001;5(4):353-61.

[117] Franco Gay ML. Spinal morphine in nonmalignant chronic pain: a retrospective study in 39 patients. Neuromodulation 2002;5(3):150-159.

[118] Grider JS, Harned ME, Etscheidt MA. Patient selection and outcomes using a low-dose intrathecal opioid trialing method for chronic nonmalignant pain. Pain Physician;14(4):343-51. 


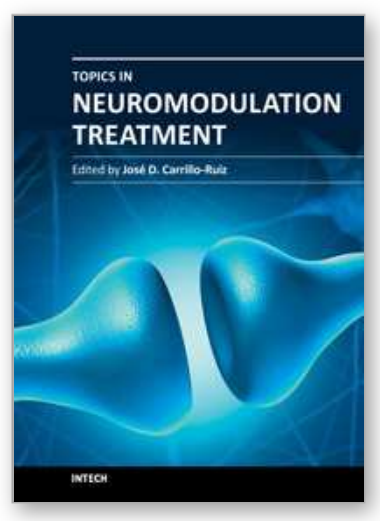

\section{Topics in Neuromodulation Treatment}

Edited by Dr. José Carrillo-Ruiz

ISBN 978-953-51-0395-0

Hard cover, 190 pages

Publisher InTech

Published online 23, March, 2012

Published in print edition March, 2012

"Topics in Neuromodulation Treatment" is a book that invites to the reader to make an update in this important and well-defined area involved in the Neuroscience world. The book pays attention in some aspects of the electrical therapy and also in the drug delivery management of several neurological illnesses including the classic ones like epilepsy, Parkinson's disease, pain, and other indications more recently incorporated to this important tool like bladder incontinency, heart ischemia and stroke. The manuscript is dedicated not only to the expert, but also to the scientist that begins in this amazing field. The authors are physicians of different specialties and they guarantee the clinical expertise to provide to the reader the best guide to treat the patient.

\section{How to reference}

In order to correctly reference this scholarly work, feel free to copy and paste the following:

William Raffaeli, Francesco Magnani, Jessica Andruccioli and Donatella Sarti (2012). Intrathecal Drug Administration for the Treatment of Cancer and Non-Cancer Chronic Pain, Topics in Neuromodulation Treatment, Dr. José Carrillo-Ruiz (Ed.), ISBN: 978-953-51-0395-0, InTech, Available from: http://www.intechopen.com/books/topics-in-neuromodulation-treatment/clinic-registry-of-implantableneurosystem-devices-and-interactions-of-opioids-drugs-with-endocrine-

\section{INTECH}

open science | open minds

\section{InTech Europe}

University Campus STeP Ri Slavka Krautzeka 83/A

51000 Rijeka, Croatia Phone: +385 (51) 770447

Fax: +385 (51) 686166

www.intechopen.com

\section{InTech China}

Unit 405, Office Block, Hotel Equatorial Shanghai

No.65, Yan An Road (West), Shanghai, 200040, China

中国上海市延安西路65号上海国际贵都大饭店办公楼 405 单元

Phone: +86-21-62489820

Fax: +86-21-62489821 
(C) 2012 The Author(s). Licensee IntechOpen. This is an open access article distributed under the terms of the Creative Commons Attribution 3.0 License, which permits unrestricted use, distribution, and reproduction in any medium, provided the original work is properly cited. 